\title{
A PRIMER ON CORPORATE GOVERNANCE IN BANKS AND FINANCIAL INSTITUTIONS: ARE BANKS SPECIAL?
}

\section{Andreas Kokkinis}

1. INTRODUCTION

A. Agency theory: Aligning the interests of managers and shareholders

i. A brief overview of agency theory

ii. Agency costs and risk-taking by companies

2. THE FAILURE OF CONVENTIONAL CORPORATE GOVERNANCE IN THE CASE OF BANKS: PROFIT MAXIMISATION V THE PUBLIC INTEREST

A. The public interest in financial stability

i. The economic significance of banks

ii. The unique business risks faced by banks

1.01

1.05

iii. Systemic risk

iv. The peculiar capital structure of banks

B. The misalignment between the interests of bank shareholders and the public interest
3. THE LIMITED POTENTIAL OF SHAREHOLDERS AND CREDITORS TO MONITOR RISK TAKING BY BANKS

A. The limits of shareholder governance of risk taking by banks 1.39

i. The opacity of banks' assets $\quad 1.40$

ii. The effect of asset opacity on risk-monitoring by bank shareholders

B. The limits of bondholder monitoring of risk taking by banks

C. The very limited risk-monitoring by depositors

4. THE EFFECT OF BANK OPACITY ON THE CORE PROBLEM OF THE MISALIGNMENT BETWEEN THE PUBLIC INTEREST AND CONVENTIONAL CORPORATE GOVERNANCE

5. TOWARDS A REGULATORY APPROACH TO BANK CORPORATE GOVERNANCE

A. The recent regulatory interventions to bank corporate governance

B. A broader reconceptualisation of bank corporate governance

6. CONCLUSION

\section{INTRODUCTION}

This chapter serves as an introductory chapter to the present volume on bank corporate governance. As such, it seeks to capture some of the specific corporate governance problems banks face, and to provide a useful background for the discussion of more detailed aspects of the topic in the forthcoming chapters. Of course, the views expressed herein are the author's own and other contributors to the volume may not agree with them. The analysis mainly focuses on UK 
banks that are listed on the London Stock Exchange, in other words, on large systemic banks. ${ }^{1}$

1.02 The corporate governance of banks is an area under continuous development which has changed dramatically in recent years both nationally and internationally. As all listed companies, UK banks are expected to comply with the UK Corporate Governance Code. ${ }^{2}$ In addition, the 2009 Walker Review introduced a series of governance recommendations specific to banks and other financial institutions. ${ }^{3}$ Many of these have since then been implemented by the PRA ${ }^{4}$ and now form part of the PRA Handbook. ${ }^{5}$ More recently, the report of the Parliamentary Commission on Banking Standards urged for broader changes to bank corporate governance including the approved persons' regime and directors' duties. ${ }^{6}$ In parallel, the fourth Capital Requirements Directive (CRD IV), impacts on bank corporate governance with regard to executive remuneration. ${ }^{7}$ Many of these issues will be explored in depth in the following chapters of this volume.

1.03 The principal aim of this chapter is to illustrate that the private ordering model of bank corporate governance is prone to lead to high negative externalities by undermining financial stability. Profit maximisation necessarily entails taking substantial risks that, even if desirable from the point of view of bank shareholders, may still be excessive from the society's perspective, due to the systemic consequences of crises in any major bank. This problem is not unique to the banking sector, but is far more severe in banks than in other large companies due to the crucial economic functions performed by banks and the special risks

1 As of 1 January 2014, the following FTSE 100 companies can be classified as banks: Barclays plc, HSBC Group plc, Lloyds Banking Group plc, the Royal Bank of Scotland Group plc and Standard Chartered plc. The discussion in this chapter also bears some relevance to other financial institutions, such as insurance companies.

2 The UK Corporate Governance Code (2012) available at: http://www.frc.org.uk/Our-Work/Codes-Standards/ Corporate-governance/UK-Corporate-Governance-Code.aspx, accessed 1 January 2014.

3 See D Walker, 'A review of corporate governance in UK banks and other financial industry entities: Final Recommendations' (2009), available at: https://www.icaew.com/en/library/subject-gateways/corporategovernance/codes-and-reports/walker-report, accessed 1 January 2014.

4 Since 2013 the FSA has been succeeded by the Prudential Regulation Authority (PRA), which is a subsidiary of the Bank of England and the Financial Conduct Authority (FCA). An analysis of the Financial Services Act 2012 can be found in A Kokkinis, 'The Financial Services Act 2012: The recent overhaul of the United Kingdom's financial regulatory structure' (2013) 24(9) ICCLR 325. See also P Rawlings, 'Bank reform in the UK: Part II - Return to the Dark Ages?' (2011) 8 ICR 55.

5 See in particular PRA Handbook, SYSC 19A.3.12-3.49.

6 See Parliamentary Commission on Banking Standards, Changing Banking for Good (2013-14, HL 27-II, HC 175-II) Chs 6-7.

7 See Directive 2013/36/EU of the European Parliament and of the Council of 26 June 2013 on access to the activity of credit institutions and the prudential supervision of credit institutions and investment firms, amending Directive 2002/87/EC and repealing Directives 2006/48/EC and 2006/49/EC [2013] OJ L176/338, art 94. See also Commission, 'Corporate governance in financial institutions and remuneration policies' COM (2010) 284 final. 
banks face, most notably, systemic risk. In addition, it will be illustrated that this problem is materially exacerbated by the limited ability of shareholder and creditor governance to curb excessive risk-taking by banks.

The chapter is structured as follows. Section 2 provides a background discussion of agency theory with a particular focus on the mechanisms that purport to align the interests of senior managers with the interests of shareholders in large widely held public companies. Section 3 explores the public market failure of the conventional corporate governance regime, that is, the negative consequences of risk-taking on the financial system and society as a whole. Then, Section 4 proceeds to demonstrate the private market failures ${ }^{8}$ of shareholder and creditor governance in the case of banks, taking each main type of creditors separately, and explains how this additional feature of the banking sector exacerbates the aforementioned problem. Section 5 builds on the previous argument by proposing a regulatory approach to bank corporate governance and ascertaining the existing regulatory intervention in the area. Section 6 summarises the discussion and concludes.

\section{A. Agency theory: Aligning the interests of managers and shareholders}

\section{i. A brief overview of agency theory}

A principal-agent relationship is a concept frequently used in economics and political science to describe a situation in which one person appoints another person to act on his behalf and in his best interests, occasionally in exchange for remuneration. ${ }^{9}$ In this sense, the relationship between voters and members of Parliament, patients and doctors, and shareholders and managers in a company are all examples of principal-agent relationships. It is worth noting that this concept of agency is broader than the legal notion of agency ${ }^{10}$ and encompasses all fiduciary relationships as well as other relationships. Frequently an agency relationship gives rise to a principal-agent problem. This happens when the agent does not have the same interests as the principal, and there is information asymmetry between the two. In other words, the agent is in possession of relevant information which is not available to - or cannot be properly understood by - the principal. In such cases the principal cannot prima facie ensure that the agent will use his powers in the principal's best interests. Assuming that

8 I am indebted to Dr Marc Moore for the useful distinction between public and private market failures. See MT Moore, Corporate Governance in the Shadow of the State (Hart Publishing 2013) 23842.

9 See J E Stiglitz, 'Principal and agent' in The New Palgrave: A Dictionary of Economics (vol 3, New Palgrave 1987) 966-71.

10 In law, an agent is a person who is given the power (the authority) to alter the legal position of another person (the principal), especially by entering into contracts on behalf of the principal. An agent's authority can be actual, which is conferred by agreement between the principal and the agent, or apparent. 
the agent is a rational actor who seeks to maximise his own utility, it can be expected that the agent will shirk his duties and may even transfer wealth from the principal to himself. ${ }^{11}$

1.06 In companies it is the separation of ownership and control, first empirically observed by Berle and Means, ${ }^{12}$ which gives rise to an agency relationship between the shareholders, who are the principals, and the directors and senior managers, ${ }^{13}$ who are their agents. The separation of ownership and control occurs when the ownership of shares is so dispersed that no shareholder - or small group of shareholders - holds a majority of shares, or even a minority interest that guarantees effective control of the company. This means that no individual shareholder (or small group) acting alone can usually determine the outcome of a shareholder vote. ${ }^{14}$ On these conditions the costs faced by shareholders who wish to attempt to influence corporate decision-making are significant, especially with regard to analysing relevant information and putting together a shareholder coalition. At the same time, the potential benefit from activism is relatively small and any benefits are equally spread among all shareholders. As a result, each shareholder is tempted to remain passive and wait for someone else to engage, a phenomenon described as the rational apathy of the shareholders..$^{15}$ The outcome of this is that the recommendations of the board are nearly invariably approved by the shareholders. This includes the election of directors, and thus in normal times boards are indeed selfperpetuating organs. ${ }^{16}$

1.07 This phenomenon, which since the late 1960s is prevalent in the UK nearly as much as in the US, gives rise to agency costs, which are imposed by senior managers to shareholders. These costs are of two types: i) lack of optimal effort and diligence by senior managers in discharging their duties; and ii) the risk that

11 A conflict of interest between the principal and the agent occurs when the personal interests of the agent clash with the interests of the principal.

12 In the early 1930s, Berle and Means' empirical work confirmed that 44 per cent of the 200 largest US corporations were managerially controlled, i.e. no single shareholder owned more than 5 per cent of shares. See A A Berle and G C Means, The Modern Corporation and Private Property (rev. edn, Harcourt, Brace \& World 1967) 108-9.

13 Although the terms are often used interchangeably in economic literature, is should be kept in mind that in law only members of the board of directors are subject to directors' duties.

14 See B S Black, 'Agents watching agents: The promise of institutional investor voice' (1991-1992) 39 UCLAL Rev 811, 821-2.

15 For a modern explanation of the dynamics of shareholder voting and the rational apathy of the shareholders from a US perspective, see C Gulinello, 'The retail investor vote: Mobilizing rationally apathetic shareholders to preserve or challenge the board's presumption of authority' (2010) 3 Utah Law Review 547, 573-6.

16 The first scholars who observed the collective action problems faced by dispersed shareholders were Berle and Means. See above n 12, 76-82 and 129-31. 
senior managers may pursue objectives other than the maximisation of shareholder wealth, such as the advancement of their own financial interests. This can be achieved (inter alia) by self-dealing, exploiting corporate opportunities, misappropriating corporate assets and receiving excessive remuneration. Additionally or alternatively, managers may pursue non-value-maximising objectives to serve their non-financial interests. An example of that is corporate 'empire-building' i.e. the creation of inefficiently large corporate groups with a view to enhance senior managers' personal power, prestige and security of office. ${ }^{17}$

In order to reduce primary agency costs, shareholders have to engage in monitoring managers by keeping themselves informed on the performance of companies and getting involved when necessary. In parallel, senior managers also wish to signal to potential investors that agency costs will be held in tight control in order to encourage investment in the company's shares. To do so, senior managers put in place majority independent boards which have the power to monitor their performance and replace them. Of course, monitoring by shareholders and using bonding devices by managers are costly activities in their own right, so they can be seen as types of agency costs themselves. This explains why Jensen and Meckling classify agency costs into three categories, namely monitoring costs, bonding costs and residual agency costs. ${ }^{18}$

In major UK banks the phenomenon of separation of ownership from control is as prevalent as in other large public companies. ${ }^{19}$ Of course, the recent partial nationalisation of RBS and Lloyds has led to the government being a substantial block holder in both these major banks. ${ }^{20}$ However, the analysis in this chapter disregards the temporary effect of the government's large investments in these banks, as the government has resolved to manage its holdings in a purely commercial manner and with a view to the quickest possible sale of its investments. ${ }^{21}$

17 Large corporations that own diverse businesses and operate in various markets are generally less susceptible to insolvency and hostile takeovers.

18 See M C Jensen and W H Meckling, "Theory of the firm: Managerial behavior, agency costs and ownership structure' (1976) 3 Journal of Financial Economics 305, 308-10.

19 Still, on a global basis, concentrated ownership is the norm in the banking sector, as 75 per cent of banks have a block holder controlling at least 10 per cent of voting rights. See G Jr Caprio, L Laeven, and R Levine, 'Governance and Bank Valuation' (2003) World Bank Working Paper No. 3202, available at: http:// papers.ssrn.com/sol3/papers.cfm?abstract_id=463240, accessed 1 January 2014.

20 The UKFI holds 82 per cent of the equity capital (66 per cent of voting rights) in RBS and 32.7 per cent of the ordinary share capital of Lloyds. In September 2013 the UKFI sold 6 per cent of Lloyds' shares, while Northern Rock was sold to Virgin Money on 1 January 2012. The Government intends to dispose of its shares in RBS in the near future, available at: http://www.ukfi.co.uk/about-us/market-investments/, accessed 1 January 2014.

21 The Government's commercial approach was challenged unsuccessfully by People and Planet, an environmental protection NGO. In $R$ (on the application of People and Planet) v HM Treasury [2009] EWHC 3020 


\section{ii. Agency costs and risk-taking by companies}

1.10 One particular aspect of the misalignment of interest between managers and shareholders is the different attitude to risk that these two groups have. The reason why we focus on risk is that, as will be demonstrated below, one of the key specific characteristics of banking is the unique risks banks face and the consequences of risk-taking by a large bank on other banks and the economy as a whole.

1.11 It is trite to say that in order for businesses to make profits they need to take risks, as business activity necessarily entails making decisions with limited information. Evidently, investors require a risk premium (i.e. a higher expected return) to invest in more risky securities. For instance, generally, corporate bonds that carry the risk that the issuing company may go insolvent bear a higher interest rate than government bonds, which are presumed to be risk-free as the government is extremely unlikely to default on its debt. ${ }^{22}$ Shares are even more risky investments as there is no specified return and share capital is the first to be lost if a company goes insolvent. As such shareholders are described as the residual risk bearers. ${ }^{23}$

1.12 Nevertheless, shareholders do not seem to be risk averse, but rather they are generally risk neutral. This is due to the practice of portfolio diversification which is followed by the vast majority of investors. According to portfolio management theory, ${ }^{24}$ investors spread their funds to different types of assets (e.g. shares, corporate bonds, government bonds, derivatives) and different issuers. Thus, only a fraction of an investor's capital will be invested in shares and this amount will be spread amongst a large number of public companies, possibly in more than one markets. As a result, the investment of any shareholder in any company is only a very small fraction of their total funds. The effect of portfolio diversification on shareholders' risk appetite is that shareholders are very close to being risk neutral. Since diversified shareholders are partly insulated from the low actual return or failure of one of their investments, as their total income is evened out by other investments, they have no reason to

(Admin) esp [34], Sales J refused the application and observed that if the government imposed its policy on climate change and human rights on the board of RBS it would be contrary to their duty to promote the success of RBS for the benefit of its shareholders as a whole. See also S F Copp, 'Section 172 of the Companies Act 2006 fails People and Planet' (2010) 31 Comp Law 406.

22 At least this is accurate for UK Government bonds. However, the recent Eurozone sovereign debt crisis demonstrates that Eurozone Government bonds are not necessarily zero risk.

23 Contractarian theory claims that the shareholders bear the residual risk. See F H Easterbrook, and D R Fischel, The Economic Structure of Corporate Law (Harvard University Press 1991) esp. 14-16.

24 See e.g. E J Elton and others, Modern Portfolio Theory and Investment Analysis (8th edn, John Wiley \& Sons Inc. 2010). 
avoid risk as such. It follows that diversified shareholders are happy for companies to take any risk which they estimate to have a positive net expected value, irrespective of the gravity of the consequences of risk taking in the worst-case scenario. ${ }^{25}$

Of course, senior managers have no immediate reason to satisfy the risk appetite of the shareholders, as in widely held companies they enjoy in practice a very wide discretion to manage companies as they think fit. ${ }^{26}$ Indeed, taking into account that managers are full-time employees who have invested their personal capital in the company, it becomes clear that they are, in general, risk averse compared to the shareholders. Human capital is not diversifiable and the potential failure of a company normally has a huge reputational cost for a senior manager and is likely to reduce his chance to obtain an equivalent position in the future. It follows that in a widely held company senior managers can be expected to be less prone to take risks than shareholders, as only the latters' investment is fully diversified.

This apparent misalignment of risk appetite between senior managers and 1.14 shareholders has been the target of academic criticism by contractarian scholars since the 1980s. Two major mechanisms have been used to align the risk appetite of the two groups: hostile takeovers and variable executive remuneration. A hostile takeover occurs when the majority of the shares - and hence the control - of a company are bought by another company without the approval of the target company's board. A hostile takeover results in the target company becoming a subsidiary of the acquire ${ }^{27}$ and in the directors and senior managers of the target being replaced. It follows that the market for corporate control ${ }^{28}$ ensures that companies' managers face a powerful incentive to do their best to maximise shareholder value, which includes adopting a neutral approach to risk-taking.

Granted, it is well established that in the banking sector hostile takeovers are uncommon both internationally ${ }^{29}$ and in the UK. ${ }^{30}$ However, major UK banks

25 The crucial significance of this point with regard to financial stability will be analysed below in Section 3.

26 On the general limitations of shareholders as decision makers and the desirability to trust the board with all business decisions, see S M Bainbridge, 'Director primacy and shareholder disempowerment' (2006) 119 Harv L Rev 1735 .

27 At least this is the practice followed in the UK. In the US it is more common for the two companies to merge.

28 US lawyer Henry Manne was the first to introduce the concept of a market for corporate control. See H G Manne, 'Mergers and the market for corporate control' (1965) 73 The Journal of Political Economy 110.

29 See e.g. S D Prowse, 'The corporate governance system in banking: What do we know?'(1997) (March) Banca del Lavoro Quarterly Review 11.

30 The only hostile takeover of a major UK bank in recent years was that of National Westminster Bank by the Royal Bank of Scotland in 2000, subsequent to a failed friendly merger of the former with Legal \& General and 
are sometimes engaged in hostile takeovers of foreign banks, ${ }^{31}$ and do frequently resort to friendly mergers, ${ }^{32}$ which are generally facilitated by the implicit threat of a possible hostile takeover. Therefore, although the pressures from the market for corporate control are somewhat limited in the special case of banks, there is still an incentive for bank senior managers to maintain the share price of the bank so as to minimise the likelihood of a hostile takeover offer arising.

1.16 The second mechanism used to achieve risk appetite alignment is variable executive remuneration. Until the 1980s, executive remuneration in large US and UK companies was generally insensitive to performance. The influential work of Jensen and Murphy in 1990 demonstrated that the remuneration of US CEOs was not strongly linked to performance, and that the overall level of CEO pay in the 1980 s was in real terms lower than in the 1930s. ${ }^{33}$ They attributed this phenomenon to the political influence of trade unions, the media and certain shareholders. Jensen and Murphy urged for an increase in variable remuneration, as better-aligned incentives would leave shareholders much better off despite the increase in overall levels of remuneration. Indeed, the 1990s brought an explosive rise of variable remuneration (especially in the form of stock options) and of overall levels of pay both in the US ${ }^{34}$ and the UK.

1.17 However, it is not clear whether variable remuneration achieves its intended goals or it is used as a device for managers to extract rents from shareholders. The influential work of Bebchuk and Fried asserts that managerial power shapes executive remuneration. ${ }^{35}$ They argue that all market forces that are supposed to restrain managerial rent-seeking, according to the optimal contacting theory, are not strong enough to bring about this outcome. In parallel, formally independent remuneration committees are frequently loyal to CEOs and depend on them for relevant information. US shareholders also have very limited direct powers to intervene in remuneration decisions. ${ }^{36}$ Hence, Bebchuk and Fried argue that managers have significant influence in deciding their

a failed hostile takeover bid by the Bank of Scotland. The takeover was central to the rise of RBS to one of the Big Four clearing banks and made it one of the largest companies in the world.

31 An obvious recent example is the takeover of ABN AMRO by a consortium led by RBS.

32 Recent examples include the merger between Lloyds TSB and HBOS in 2009, the acquisition of Abbey National by Santander in 2004, the merger of Halifax and Bank of Scotland in 2001, and the acquisition of the Midland Bank by HSBC in 1992.

33 See M C Jensen, and K J Murphy, 'CEO incentives - It's not how much you pay, but how' (1990) (May-June) Harvard Business Review 138.

34 In the US the favourable tax treatment of variable remuneration since 1993 further facilitated the shift towards performance-based pay.

35 See L A Bebchuk, J M Fried, and D I Walker, 'Managerial power and rent extraction in the design of executive compensation' (2002) 69 U Chi L Rev 751, esp. 789-94.

36 In the UK shareholders are given broader approval powers by the Companies Act 2006, ss 439-439A. 
own remuneration. In addition, various forms of performance-based remuneration have been criticised as depending on luck and rewarding executives for merely increasing the volatility of their company's share price rather than its profitability. Executive pay can therefore be a source of agency costs, rather than a tool to minimise them. ${ }^{37}$

\section{THE FAILURE OF CONVENTIONAL CORPORATE GOVERNANCE IN THE CASE OF BANKS: PROFIT MAXIMISATION V THE PUBLIC INTEREST}

\section{A. The public interest in financial stability}

The previous section offered a brief overview of agency theory and conventional corporate governance techniques with a special emphasis on the ways in which corporate governance fosters risk-taking by the senior managers of large companies within the broader framework of shareholder value maximisation. In this section I explain why running major banks with a view to profit maximisation potentially undermines financial stability. The misalignment between the private interests of bank shareholders and the public interest is arguably the major distinct characteristic of the banking sector which warrants a radically different approach to bank corporate governance which would not be necessarily appropriate for non-financial companies. ${ }^{38}$ As a preliminary point, this part identifies the specific economic characteristics of the banking sector that render financial stability a public good and justify its crucial importance for the economy as a whole. ${ }^{39}$

A detailed doctrinal analysis of financial stability as the statutory objective of relevant UK regulatory authorities falls outside the scope of the chapter. It is sufficient to note here the recent legislative emphasis on financial stability, as a response to the financial crisis. Indeed, the Banking Act 2009 added section 2A to the Bank of England Act 1998 and thus added to the Bank's statutory

37 Jensen and Murphy (in spite of their original contribution to the optimal contracting theory) have criticised prevailing executive remuneration practices during the 1990s, and admitted in 2004 that executive pay was excessive and still not truly aligned with corporate performance. See M C Jensen, K J Murphy and EG Wruck, 'Remuneration: Where we've been, how we got to here, what are the problems, and how to fix them' (2004) Harvard Business School NOM Research Paper No. 04-28, 98, available at: http://ssrn.com/abstract=561305, accessed 1 January 2014.

38 See e.g. P Ciancanelli and J A Reyes-Gonzalez, 'Corporate governance in banking: A conceptual framework' (European Financial Management Association conference, Athens, June 2000), available at: http://ssrn.com/ abstract=253714, accessed 1 January 2014.

39 A public good is a good that is both indivisible and one that no person can be excluded from its use, such as national defence. It is a case of market failure, as markets cannot produce public goods at the socially desirable level. 
objectives a financial stability objective. ${ }^{40}$ The latter was further strengthened by the Financial Services Act 2012 which amended the financial stability objective by asserting that the Bank ought to protect and enhance the stability of the financial system of the UK rather than merely to contribute to protecting and enhancing stability, as the previous wording of the section was. ${ }^{41}$ In addition, the 2012 Act introduced the Financial Policy Committee of the Bank of England which is charged with contributing to the achievement of the Bank's financial stability objective. ${ }^{42}$ Finally, the broader restructuring of the banking regulatory landscape can be said to prioritise macro-prudential issues over micro-prudential ones, and separates prudential regulation from conduct of business regulation thus allowing for greater focus on financial stability than under the previous structure..$^{43}$

\section{i. The economic significance of banks}

1.20 First, I shall briefly explain the vital importance of the financial sector and of banks in particular for any modern economy. As financial intermediaries banks efficiently transfer liquidity from depositors and bondholders to individual, corporate and sovereign borrowers, allowing for economic growth and expansion. In fact they generate liquidity, as they fund illiquid assets (loans) using the money deposited in them. ${ }^{44}$ Indeed, by accepting deposits and relending most of them and then reaccepting the money back (as after certain transactions it goes back to the bank) and relending it, and so on, circulating money is multiplied several times. This is the so-called money multiplying effect, which explains the need to supervise overall lending by the authority charged with monetary policy. ${ }^{45}$

1.21 In addition, banks operate a complex payment services system which facilitates the transactions of their private and corporate clients, inter alia, via cheques, credit cards, debit cards, cash cards, electronic purses, money transfers, and

40 Banking Act 2009, s 238 (1).

41 Financial Services Act 2012, s 2 (2).

42 See Bank of England Act 1998, s 9C (inserted by the Financial Services Act 2012, s 4).

43 On that, see Kokkinis, see above n 4.

44 Of course, financial intermediation is not the only activity of banks in recent years. It has been illustrated that the financial intermediation role of banks is nowadays less important than in the past, as their main source of income is fees and trading activities rather than the margin between interest rates paid by borrowers and interest rates paid to depositors. See e.g. F Allen, and A M Santomero, 'What do financial intermediaries do?' (2001) 25 Journal of Banking E Finance 271.

45 In the UK monetary policy is independently administered by the Bank of England (and its Monetary Policy Committee) within the inflation target set by the Treasury. See Bank of England Act 1998, s 10 which abolishes the power of the Treasury to give direction to the Bank with regard to monetary policy; and s 11 which lexically prioritises the Bank's objective to maintain price stability above its duty to support the Government's economic policy. 
standing orders. In this way banks can be said to resemble utility companies providing an intangible network of essential importance for society as a whole. Banks are also large employers, especially in countries like the UK where the financial sector accounts for nearly 10 per cent of the GDP. Last but not least, banks significantly influence the corporate governance of other companies through debenture covenants and informal monitoring of financed companies.

Furthermore, the occurrence of a bank crisis has detrimental consequences for the real economy. First, bank lending is curtailed as ailing banks seek to reduce their loan portfolios. The resulting credit crunch undermines the ability of firms to raise debt and expand, and can thus cause the economy as a whole to enter into a recession ${ }^{46}$ and unemployment to rise. ${ }^{47}$ To make matters worse, Government spending to prevent the failure of large banks (and thus the collapse of the financial system), and the overall economic recession leads to the inescapable consequence of increasing the public debt with potentially serious long-term consequences for the economy. ${ }^{48}$ It seems that whatever policy is followed to manage a banking crisis, serious negative externalities are generated when a large bank fails, and the losses are borne not only by other banks but also by the real economy and taxpayers. Indeed, the consequences of bank crises are so severe that it is highly unlikely that any benefits accruing from increased risk taking during the period leading up to a crisis (e.g. in the form of lower unemployment and faster growth) will outweigh the cost of a financial crisis (although formal economic evidence on this is difficult to find). ${ }^{49}$

\section{ii. The unique business risks faced by banks}

Due to the maturity mismatch between: on the one hand, deposits, that are typically payable on demand, and, on the other, loans, that are to be repaid after a fixed period, it follows that no bank can meet a significant fraction of its liabilities at any given time. Banks cannot even do so relatively quickly, as their

46 For instance, in 2009 UK GDP declined by 4 per cent as a result of the 2008 financial crisis.

47 The unemployment rate rose from around 5.3 per cent in 2007 to 8 per cent in 2011 and is predicted to be at 7.3 per cent in 2015. See European Economic Forecast Autumn 2009 (2009), available at: http://ec.europa.eu/ economy_finance/publications/publication_summary16053_en.htm, accessed 1 January 2014, 156; and European Economic Forecast Autumn 2013 (2013), available at: http://ec.europa.eu/economy_finance/eu/ forecasts/2013_autumn_forecast_en.htm, accessed 1 January 2014, 101.

48 The UK national debt to GDP ratio increased from 43.30 per cent at the end of the 2007-08 fiscal year to 88.10 per cent at the end of 2012-13. It is predicted to rise to 97.80 per cent by the end of the 2015-16 year. Ibid.

49 The UK Government's support to the banking sector peaked at $£ 1,162 \mathrm{bn}$ in 2009 and currently stands at $£ 141 \mathrm{bn}$. The exact final cost to UK taxpayers is difficult to calculate as it will ultimately depend on the price at which the Treasury's shares in rescued banks are sold. Taking into account the share prices of RBS and Lloyds at 31 March 2013, the loss to the Treasury stood at $£ 28 \mathrm{bn}$. Another $£ 3$ bn was the cost of resolving Northern Rock and Bradford \& Bingley. The additional interest paid by the Treasury to fund its investments in the banking sector amounts to $£ 20 \mathrm{bn}$ in four years. Overall, the cost of the recent crisis to the Treasury can be estimated at £51bn. See HM Treasury, Annual Report and Accounts 2012-13 (2013-14, HC 34). 
assets are illiquid and cannot therefore be sold en masse at short notice, other than at very low prices. If a large number of depositors are persuaded that their bank is in a precarious position and rush to draw their funds, they will cause the collapse of the bank, no matter how healthy it is. In other words, the inability of rational depositors to coordinate their actions ${ }^{50}$ can lead to a creditors' run, if the reputation of a bank is damaged. A run reduces depositors' aggregate wealth in a classic collective action problem situation. Therefore, any retail bank is constantly dependent on the confidence of its depositors and can at any time be diminished to cash flow insolvency merely as a result of a crisis of confidence. ${ }^{51}$ This is a feature of banks that distinguishes them from ordinary companies whose assets are usually more easily realisable and whose liabilities such as term loans and bonds mature over a relatively long and predictable period of time.

1.24 Furthermore, investment banking activities such as trading in securities, on behalf of clients or on banks' own behalf, exposes banks to the volatility of the financial markets. It follows that investment banks, which in the UK are integrated parts of banking groups, are susceptible to sharp changes in their risk profile due to their sensitivity to the conditions of financial markets. It is often argued that the combination of retail and investment banking activities further increases the risks faced by banks, and that this accounts for the number of banking crises that have happened internationally since the integration of retail and investment banking in the 1980s and 1990s. ${ }^{52}$

\section{iii. Systemic risk}

1.25 The major feature of the banking industry which renders financial stability a public good is systemic risk. So far it has been explained why individual banks face specific risks that are not faced (at the same extent) by other companies. However, if the failure of one bank left its competitors strengthened and the system intact, as is the case in most other industries, the problem of safeguarding financial stability would not arise. On the contrary, the failure of a relatively large bank has spill-over effects on the entire system. Other major banks suffer and a series of failures may be triggered. Problems in one bank can thus infect

50 See M C Ungureanu, 'Banks: Regulation and corporate governance framework' (2008) 5 Journal of Corporate Ownership and Control 449, 450-51.

51 Deposit insurance reduces the risk of creditors' runs and thus protects financial stability.

52 In the UK the Vickers Report recommended a mild form of separation of retail banking from investment banking known as ring fencing of the domestic retail activities of banking groups, which are to be taken by a separate subsidiary with stronger capital. See Independent Commission on Banking, Final Report: Recommendations (2011), available at: http://webarchive.nationalarchives.gov.uk/+/bankingcommission.independent. gov.uk, accessed 1 January 2014, esp. para 9.2. Recently, Policy Exchange, a major think tank published a report which criticises ring fencing as likely to bring more costs than benefits. See Policy Exchange, Ring fencing UK Banks: More of a problem than a solution (J Barty (ed.), Heron, Dawson and Sawyer 2013). 
the whole of the financial system and lead to a serious banking crisis, as happened in the UK in 2007-09.53

This phenomenon is due to the very high interconnection and interdependence of banks, which conduct a major part of their business with other banks. ${ }^{54}$ Banks, for instance, rely on the inter-bank lending market to ensure that they have adequate liquidity to meet their liabilities. They borrow large sums for short periods of time from other banks to respond to frequent shortages of liquidity due to various reasons such as an increase in the withdrawals of deposits. Another component of systemic risk is the reputational one. The failure of an important bank may cause a crisis of confidence in the system as a whole and depositors' runs may affect other banks, or at least an increase in deposit withdrawals may occur. Finally, the opacity of the sector, which will be explored in detail in Section 3 of the chapter, is a cause of systemic risk. ${ }^{55}$ The inability of other banks to value the assets of an ailing bank precipitates the collapse of the latter. In parallel, the inability of financial markets to distinguish between sound and unsound banks in times of crisis can paralyse inter-bank lending, and makes it more difficult for banks to raise additional equity capital in times of crisis. Similarly, the general inability of depositors to distinguish between sound and unsound banks, precipitates a widespread crisis of confidence once a major bank collapses. ${ }^{56}$

\section{iv. The peculiar capital structure of banks}

To appreciate the magnitude of the threat that systemic risk poses to financial stability it is necessary to refer to another peculiar characteristic of banks, namely their heavy reliance on debt finance. In banks, as in all limited liability companies, insolvency risk increases the more highly leveraged the company is. Indeed, if a company's activities are mostly funded by equity, then there is a large buffer to absorb losses and hence insolvency is unlikely. Conversely, if a

53 For a succinct discussion of the main banking failures in the UK, see E Walker-Arnott, 'Company law, corporate governance and the banking crisis' (2010) 7 ICR 19, 19 and 24-26.

54 See P Mulbert, 'Corporate governance of banks after the financial crisis - Theory, evidence, reforms' (2010) ECGI Working Paper No. 151/2010,11-12, available at: http://papers.ssrn.com/sol3/papers.cfm?abstract_id= 1448118, accessed 1 January 2014.

55 A recent empirical study on the banking industry found evidence that suggests that opacity causes contagion by exacerbating the cycles of bubbles and crashes. In other words, more opaque banks benefit in times of euphoria and then suffer in times of crisis. See J S Jones, W Y Lee, T J Yeager, 'Opaque banks, price discovery, and financial instability' (2012) 21 Journal of Financial Intermediation 383.

56 It has been empirically confirmed that financial crises have a long-term negative effect on investor confidence. Immigrants to the US who have experienced a bank crisis in their country of origin are less likely to open a bank account. See U O Osili and A Paulson, 'Bank crises and investor confidence: An empirical investigation' (2008) Federal Reserve Bank of Chicago Working Paper No. 2008-17, available at: http://www.chicagofed.org/ webpages/publications/policy_discussion_papers/2009/pdp_9.cfm, accessed 1 January 2014 
company relies primarily on debt capital, it runs a higher risk of insolvency if for any reason its income is reduced, the value of its assets decreases or it fails to roll-over its debt. ${ }^{57}$ Unlike most other large companies, banks rely heavily on debt capital. A typical bank is approximately 95 per cent debt financed ${ }^{58}$ (deposits and bonds) and only 5 per cent equity financed. Indeed, the equity to assets ratios ${ }^{59}$ of major UK banks are currently in the area of 5 per cent (and hence their gearing ratio is in the area of 1:19), and have consistently been at approximately that level in recent years, as can be seen in Table 1.1.

Table 1.1 FTSE 100 UK banks' equity to assets ratio 2000-12

\begin{tabular}{lccc}
\hline & $31 / 12 / 2000$ & $31 / 12 / 2006$ & $31 / 12 / 2012$ \\
\hline Barclays & $4.17 \%$ & $2.83 \%$ & $4.22 \%$ \\
HSBC & $6.49 \%$ & $5.97 \%$ & $6.20 \%$ \\
HBOS & $4.10 \%$ & $3.58 \%$ & $\mathrm{NA}$ \\
Lloyds & $4.57 \%$ & $3.35 \%$ & $4.83 \%$ \\
RBS & $7.22 \%$ & $4.60 \%$ & $5.19 \%$ \\
Standard Chart. & $5.74 \%$ & $5.22 \%$ & $7.24 \%$ \\
\hline
\end{tabular}

Note: For 2012, the table measures Tier 1 equity rather than Core Tier 1 equity (introduced after the recent crisis) to achieve comparability with 2000 and 2006 data.

Source: All data is taken from the Annual Reports and Accounts of the relevant banks, which can be found online.

1.28 The reason why banks are far more highly leveraged than other companies is that their profitability rises as their equity to assets ratio falls. ${ }^{60}$ Unlike generic companies, banks do not incur debt in order to do business, but rather their core business activity is to incur debt by accepting deposits and lending the funds out to borrowers. Hence, if we apply the balance sheet test of insolvency on banks, they will always be near-insolvent, as their liabilities are nearly equal to their assets. Therefore, even when banks are perfectly healthy, their capital structure resembles that of a near-insolvent, non-bank firm. The outcome of this is that bank shareholders have stronger economic incentives to support a high level of risk taking than the shareholders of generic companies. As banks are very highly leveraged, shareholders have the incentive to push managers to adopt

57 If markets were perfect the capital structure of a company would not matter with regard to profitability, as posited by the Modigliani-Miller theorem.

58 See J R Macey and M O'Hara, 'The corporate governance of banks' (2003) 9 Federal Reserve Bank of New York Economic Policy Review 91.

59 Equity includes called-up share capital, preference shares, the share premium account, the profit and loss account, other reserves, and minority interests.

60 An economic explanation of the reason why banks are so highly leveraged can be found in $\mathrm{H}$ DeAngelo and $\mathrm{R}$ M Stulz, 'Why high leverage is optimal for banks' (2013) Fisher College of Business Working Paper, available at: 2013-03-08 http://papers.ssrn.com/sol3/papers.cfm?abstract_id=2254998, accessed 1 January 2014. 
very risky strategies as they risk only their relatively small investment and reap the benefits from 'betting' the whole of a bank's balance sheet, which is mostly funded by debt.

\section{B. The misalignment between the interests of bank shareholders and the public interest}

Having examined the idiosyncratic economic characteristics of banks which render financial stability a public good, in this part I argue that there is a fundamental misalignment between, on the one hand, the private interests of dispersed shareholders, and on the other, the general public interest in financial stability. The main problem is that the level of risk, which is optimal from the point of view of bank shareholders, will tend to be excessive from the point of view of society.

Generally, rational dispersed shareholders prefer the corporate strategy with the highest risk-adjusted return, even if it engenders a risk to the company's survival, since they are risk-neutral and seek to maximise the economic returns on their investment. It follows that rational dispersed shareholders would be happy to support a corporate strategy with high net expected returns even if this strategy involves a low probability risk that the bank will face serious troubles or fail.

Table 1.2 provides an illustration of the point that in some cases it is valuemaximising for rational shareholders of a bank to prefer a business strategy with a high net risk-adjusted value which may lead to the failure of the bank. All figures are hypothetical. They show the expected value of a bank, after two alternative strategic options (a conservative and an aggressive one) have been implemented at point $B$ in time. The initial value of the bank is 100 (at point $A$ in time). In both cases there is a good scenario ( 99 per cent probability of happening) and a bad scenario ( 1 per cent probability of happening). The expected value of the bank at point $B$ is the weighted average of values in the good and bad scenario. ${ }^{61}$ As can be seen in the table, taking the risky option which entails a 1 per cent risk of the bank going insolvent leads to a higher expected profit than taking the safe option which does not jeopardise the bank's survival.

61 For strategy A, this is $99 \%$ x $102+1 \%$ x 101, which equals to $100.98+1.01=101.99$. Therefore the expected profit is $101.99-100=1.99$. For Strategy B, this is $99 \% \times 104+1 \% \times 0$, which equals to $102.96+0=102.96$. Therefore the expected profit is $102.96-100=2.96$. 
Table 1.2 Rational shareholders' attitude to risk

\begin{tabular}{|c|c|c|c|c|c|}
\hline & \multirow{2}{*}{$\begin{array}{l}\text { Bank } \\
\text { value at } \\
\text { point } A\end{array}$} & \multicolumn{3}{|c|}{ Bank value at point $B$} & \multirow{2}{*}{$\begin{array}{l}\text { Expected } \\
\text { profit (exp } \\
\text { value at } B- \\
\text { value at } A \text { ) }\end{array}$} \\
\hline & & $\begin{array}{l}\text { Good } \\
\text { scenario } \\
(99 \%)\end{array}$ & $\begin{array}{l}\text { Bad } \\
\text { scenario } \\
(1 \%)\end{array}$ & $\begin{array}{l}\text { Expected } \\
\text { value at } \\
\text { B }\end{array}$ & \\
\hline Strategy 1 & 100 & 102 & 101 & 101.99 & 1.99 \\
\hline Strategy 2 & 100 & 104 & 0 & 102.96 & 2.96 \\
\hline
\end{tabular}

1.32 In other industries, this phenomenon is unproblematic as company failures are not perceived as a problem but rather as a manifestation of the operation of market forces that ensure the efficient allocation of capital and hence the development of the economy. Indeed, limited liability itself and the relatively low standard of care imposed on company directors ${ }^{62}$ are legal institutions designed to encourage risk-taking. However, in the banking sector the failure of a major bank can have systemic consequences and foster a crisis, which then has catastrophic consequences on the economy as a whole.

1.33 Systemic risk does not reduce the incentives of the shareholders of individual banks to encourage the aforementioned level of risk taking. Indeed, if rational shareholders of hypothetical major bank $A$ expect that all other systemic banks will engage in high risk-taking to maximise their profits, it still makes sense from their point of view to do the same, despite the potential negative consequences of this behaviour to the financial system as a whole. If all the shareholders of all systemic banks could collectively agree on a level of risk taking, they would take into account systemic risk and would refrain from taking the level of risk that seemingly maximises profits at the level of each bank. However, given the inability of bank shareholders to co-ordinate at an industry-wide level, ${ }^{63}$ the shareholders of each bank face a rational incentive to support a profit maximisation policy, as they will in any case suffer the consequences of risk taking by other banks, if the latter leads to a systemic crisis.

1.34 This is an example of a prisoner's dilemma situation, where the inability of 'players' to co-ordinate leads to an outcome that reduces the aggregate wealth of the players. It follows that the current bank corporate governance regime does

62 On bank directors' duties, see Chapter 3 of this volume.

63 Collective action by dispersed shareholders is difficult even at the level of individual companies. On the limited cooperation between institutional shareholders of UK companies, see B S Black, and J C Jr Coffee, 'Hail Britannia? Institutional investor behavior under limited regulation' (1993-94) 92 Mich L Rev 1997. On a sector wide basis, co-ordination would be even more difficult to achieve especially given the increasing fragmentation and internationalisation of share ownership in recent years, On this, see B R Cheffins, 'The Stewardship's Code Achilles Heel' (2010) 73 MLR 1004, esp. 1017-23. 
not necessarily maximise the aggregate wealth of the shareholders of all systemic banks, as the run of each bank to maximise its profits decreases the overall expected value of the system. This is not to say that any strategy that would be optimal for the shareholders of all systemic banks would necessarily be compatible with the public interest, as the problem of negative externalities caused by bank failures would persist. Rather, it means that financial stability is a public good both for society as a whole, and for the shareholders of systemic banks as a whole. Still, systemic bank shareholders, if capable of co-ordinating, would favour taking more risk than is in the society's interest, but less risk than they tend to accept absent co-ordination.

Therefore, where risk-taking is concerned, banking regulators (representing the public interest) and bank shareholders are markedly different. A shareholderoriented corporate governance system is thus likely to lead to constant pressures on banks' senior management to take on excessive risks. This is not merely a theoretical assertion. Evidence given by major UK banks in Parliament demonstrates that in the years up to the 2007 crisis most active bank shareholders enthusiastically supported further increases in leverage and balance sheet restructurings with a view to increase short-term profits. ${ }^{64} \mathrm{In}$ addition, performance-based remuneration incentivised bank managers to take very high risks and may thus have contributed to the making of catastrophic strategic decisions that led to the recent financial crisis. ${ }^{65}$

As a result, the prevalent managerial norm of shareholder value maximisation, embedded in section 172 (1) of the Companies Act 2006, and practically enforced via performance-based remuneration, the market for corporate control and institutional shareholder activism, leads to banks adopting a risk profile that may seem to be optimal for their shareholders but is detrimental to

64 Parliamentary Commission on Banking Standards, Changing Banking for Good, see above n 6, paras 326-327. There is also strong empirical evidence that internationally these banks that have more institutional shareholders took higher risks before the crisis and suffered more during the crisis. See D H Erkens, M Hung and P Matos, 'Corporate governance in the 2007-2008 financial crisis: Evidence from financial institutions worldwide' (2012) 18 Journal of Corporate Finance 389. Given that institutional shareholders are the main type of shareholder who are risk neutral (unlike block holders who are not diversified) and capable of influencing banks' behaviour (unlike small individual shareholders), this evidence suggests that shareholder pressures have contributed to excessive risk taking.

65 There is empirical evidence that the financial benefits that accrued to the senior managers of failed US banks during the years leading up to the crisis exceed the losses the managers suffered as a result of the collapse of their institutions. See L A Bebchuk, A Cohen and H Spamann, 'The wages of failure: Executive compensation at Bear Sterns and Lehman 2000-2008' (2010) 27 Yale Journal of Regulation 257. See also R DeYoung, E Y Peng and M Yan, 'Executive compensation and business policy choices at U.S. Commercial Banks' (2013) 48 Journal of Financial and Quantitative Analysis 165. 
financial stability. ${ }^{66}$ This finding justifies the regulation of risk taking by banks and provides prima facie support to a regulatory approach in dealing with major bank corporate governance problems ${ }^{67}$ such as board composition, and executive remuneration. ${ }^{68}$

\section{THE LIMITED POTENTIAL OF SHAREHOLDERS AND CREDITORS TO MONITOR RISK TAKING BY BANKS}

1.37 Corporate governance structures, such as performance-based remuneration and the market for corporate control, provide senior managers with powerful incentives to take substantial risks in line with the risk appetite of fully diversified shareholders. However, the inadequate design of remuneration packages and the short-term investment horizons of many shareholders can lead to a situation where it is in the personal interest of senior managers to take more risk than fully informed shareholders with a long-term commitment to the company would accept. ${ }^{69}$ In theory, the incorporation of long-term prospects into the market price of shares ${ }^{70}$ and enhanced monitoring of corporate performance by - at least some of - the institutional shareholders ${ }^{71}$ should prevent such a problem from arising at all. In parallel, monitoring by the main providers of debt capital to companies such as bondholders and major creditors also operates as a check on excessive risk-taking especially given the legal position of creditors. In perfect market conditions, monitoring by shareholders and creditors precludes the assumption of a level of risk that is not in the private interests of these groups, as the level of risk taken is fully reflected in the value of companies' shares and bonds and on the interest rates paid by companies to their creditors. ${ }^{72}$

66 In that sense, it has been argued that it was not the failure but the success of (conventional) corporate governance that led to the recent crisis See N C Howson, "When "Good" corporate governance makes "Bad" (financial) firms: The global crisis and the limits of private law' (2009) 108 Mich L Rev (First Impressions) 44, 49-50.

67 On the importance of the corporate governance framework from the perspective of prudential regulation, see A Kokkinis, 'Rethinking banking prudential regulation: Why corporate governance rules matter?' (2012) 7 JBL 612.

68 On these aspects of bank corporate governance see below Chapters 2, 3, 4 and 5 of this volume.

69 This problem has given rise to a much greater emphasis on risk management at board level in recent years. On this, see M T Moore, 'The evolving contours of the board's risk management function in UK corporate governance' (2010) 10 J Corp L Stud 279.

70 According to the efficient markets hypothesis, all publicly available information is reflected on the prices of shares. On this, see E Fama, 'Efficient capital markets: A review of theory and empirical work' (1970) 25 The Journal of Finance 383.

71 Here I refer to institutional investors who manage their portfolio actively, rather than to passive index funds which invest across the market.

72 In addition, in a perfect market all corporate constituencies would protect themselves against risk-taking by a company. For instance, employees would bargain for a higher salary to compensate themselves for the increased risk of the company failing and them being dismissed. 
This section argues that risk-monitoring by market players is unlikely to be effective in the case of banks, whose business, assets, capital structure, and regulatory framework is different than that of generic companies. By saying so, I do not purport to imply that in non-financial public companies markets work perfectly efficiently and the level of risk taken is aligned with the interests of all their private constituencies. There is a widespread concern that UK equity markets are permeated by short-termism and investor myopia. This phenomena arguably lead to under-investment in sound long-term projects and to an excessive emphasis on corporate restructurings and portfolio management and possibly perverse incentives to follow excessively risky business or financing strategies. ${ }^{73}$ My argument is that banks face essentially the same problems in this regard as all major public companies, but that due to the special nature of the banking sector, these problems are generally more severe in banking than in generic companies. I proceed by first explaining the limits of risk monitoring by bank shareholders, then by bondholders and finally by depositors, who provide the greatest part of bank capital.

\section{A. The limits of shareholder governance of risk taking by banks}

To appreciate the limitations of shareholder monitoring of risk-taking by banks it is necessary to provide some background on the specific nature of banks' business and assets, namely the so-called opacity of banks' assets. There is some confusion in this area due to the way that the efficient market hypothesis is often misinterpreted. ${ }^{74}$ The efficient market hypothesis is a model that purports to provide a generally plausible abstraction of reality and (in its semistrong version) claims that the prices of shares and other securities reflect publicly available information. ${ }^{75}$ It does not claim that market prices reflect the fundamental or inherent value of securities. As there is no way to observe the intrinsic value of a security, we can only conclude ex post facto that at some point in time a security was overvalued. An example of this is the shares of a

73 These concerns prompted a BIS consultation and the publication of the influential Kay Review which acknowledges the need to focus on relationships of trust between market players rather than on a trading culture. See BIS, available at: 'A long-term focus for corporate Britain - A call for evidence' (2010), available at: https://www.gov.uk/government/consultations/a-long-term-focus-for-corporate-britain-a-call-for-evidence, accessed 1 January 2014; J Kay, 'The Kay Review of UK equity markets and long-term decision making: Interim Report' (2012), available at: https://www.gov.uk/government/news/kay-review-of-equity-markets-publishesinterim-report, accessed 1 January 2014; and 'The Kay Review of UK equity markets and long-term decision making: Final Report' (2012), available at: https://www.gov.uk/government/news/kay-review-publishesreport-on-uk-financial-sector, accessed 1 January 2014.

74 On the frequent misinterpretation of the hypothesis, see the insightful analysis of $\mathrm{R}$ Ball, 'The global financial crisis and the efficient markets hypothesis: What have we learned?' (2009) 21 Journal of Applied Corporate Finance 8.

75 For a critical discussion of the hypothesis, see L A Stout, 'The mechanisms of market inefficiency' (2003) 28 Journal of Corporation Law 635. 
company that engages in fraudulent accounting practices (e.g. Enron ${ }^{76}$ ) until the fraud is disclosed. Furthermore, there is nothing in the efficient markets hypothesis that implies that past returns on a security will be repeated in the future. The unprecedented movements in share prices during the recent financial crisis do not therefore undermine the validity of the efficient markets hypothesis, but rather suggest that risk in financial markets is non-stationary. ${ }^{77}$ Therefore, the extent to which the market price of securities reflects their fundamental value depends on the quality of available information and on the costs investors face to acquire and process information.

\section{i The opacity of banks' assets}

1.40 The argument here is that in the case of banks relevant information is more difficult to process than in other companies both by banks themselves in preparing their financial disclosures to the market, and by investors and analysts when they adjust their behaviour subsequent to a disclosure. If this is the case, we may infer that the shares of banks will be more volatile than other shares for a considerable period after a financial crisis, ${ }^{78}$ and that there will be scope for banks' senior managers to influence the share prices of banks in normal economic conditions - until the true state of affairs becomes apparent to the market. In the following paragraphs I seek to explain why processing information on banks' financial performance is particularly difficult.

1.41 There is a considerable body of financial literature that focuses on banks and questions whether banks are specific in their market behaviour and governance problems. ${ }^{79}$ More recent research highlights the specificity of banks, especially with regard to the opacity (or opaqueness) of their assets and the regulatory

76 An academic analysis of the Enron scandal focusing on the limited independence of auditors can be found in D Kershaw, 'Waiting for Enron: The unstable equilibrium of auditor independence regulation' (2006) 33 Journal of Law and Society 388.

77 A non-stationary process is a stochastic process whose joint probability distribution is not constant when shifted in time. There is a rich body of relevant mathematical literature, but its examination fall outside the scope of this volume.

78 Indeed, the volatility of bank shares increased sharply since 2008 and has remained at high levels compared to the shares of non-financial companies since then. See e.g. A Atkeson and W E Simon Jr, 'The rising fear in bank stock prices' The Wall Street Journal (28 November 2011), available at: http://online.wsj.com/news/ articles/SB10001424052970204531404577052493270860130, accessed 1 January 2014.

79 Early American literature on the subject generally viewed banks as not posing any special governance problems. See e.g. A Saunders, E Strock, and N G Travlos, 'Ownership structure, deregulation and bank risk-taking' (1990) 45 The Journal of Finance 643; L Allen, and S A Cebenoyan, 'Bank acquisitions and ownership structure: Theory and evidence' (1991) 15 Journal of Banking and Finance 425; SD Prowse, 'Alternative methods of corporate control in commercial banks' (1995) Federal Reserve Bank of Dallas Economic and Financial Policy Review 3, 24; A J Crawford, J R Ezzell, and J A Miles, 'Bank CEO pay-performance regulations and the effects of deregulation' (1995) 68 Journal of Business 231. 
framework within which they operate. ${ }^{80}$ The reason that banks are more opaque than other companies ${ }^{81}$ is that their assets consist primarily of claims against borrowers, and financial instruments. A loan portfolio is far more difficult to value than most other assets, such as manufacturing plants and machinery. Of course, some loans are secured by mortgages or charges so that the bank's claim can be satisfied by selling the collateral in the case of a borrower's default. Still, security does not eliminate the risky nature of loans, since the value of the collateral may not be sufficient to cover the whole claim, especially if there are sharp changes in the relevant market ${ }^{82}$ or if accrued interest and penalties have significantly increased the amount of the claim. Furthermore, it is very challenging for an external investor to assess the quality of loans and to predict the rate of defaults, as this depends on the creditworthiness of individual personal and corporate borrowers.

Securitisation of loans and investment banking activities such as proprietary trading in various securities ${ }^{83}$ on behalf of banks further exacerbates asset opacity. The process of securitisation which became extremely popular until the recent crisis involves a bank selling a number of loans to a special purpose vehicle (a separate company) which then issues debt instruments to investors on the collateral of the income stream from the loans. For instance, asset-backed securities (ABSs) are debt instruments serviced by the cash flows of a discrete pool of fixed or revolving assets (e.g. mortgages, credit cards, student loans, etc). Collateralised debt obligations (CDOs) are structured ABSs, divided into different risk tranches. Senior tranches are to be serviced first so they are in theory safe even if the underlying loans are given to borrowers with low creditworthiness. The complex nature of the securitisation process arising out of packaging together loans of different nature and risk, and the uncertainty with regard to the continuing liability of the originating bank in case of default of the special purpose vehicle (SPV), exacerbate asset opacity as investors are likely to disagree about the value of such instruments. Indeed, Cheng et al found in 2008 that US banks which engaged in securitisation were more opaque

80 See e.g. R Levine, 'The corporate governance of banks: A concise discussion of concepts and evidence' (2004) World Bank Policy Research Working Paper 3404, available at: http://elibrary.worldbank.org/doi/book/ 10.1596/1813-9450-3404, accessed 1 January 2014; A Polo, 'The corporate governance of banks: The current state of the debate' (2007), available at: http://ssrn.com/abstract=958796, accessed 1 January 2014; Macy and O’Hara, see above n 58; Ungureanu, see above n 50; D Heremans, 'Corporate governance issues for banks. A financial stability perspective' (2007) University of Leuven Working Paper, available at: http://ssrn.com/ abstract=1024693, accessed 1 January 2014; Mulbert, see above n 54 .

81 See Levine, see above n 80, 7-9.

82 The collapse of the US real estate market undermined the value of the collateral banks possessed. This caused a sharp fall in the prices of mortgage-backed securities, which came to be known as toxic assets.

83 These include several types of securities such as derivatives and options. Credit default swaps for instance are contracts whereby the protection buyer makes a series of payments to the protection seller in exchange for a pay-off in the event that the underlying credit instrument, bond or loan, defaults. 
than those that did not, and that opacity increased in tandem with the size of securitised assets. ${ }^{84}$

1.43 Given that bank assets are difficult to value, we should expect that in times of financial turmoil, when a substantial number of borrowers default, banks' opacity would deteriorate as banks face a strong incentive to conceal their losses by preserving or refinancing troubled loans rather than calling off the facilities and reporting them as non-serviced loans. Given that banks with troubled assets will not disclose the extent of their losses, the market will - in all likelihood - be unable to distinguish between 'good' and 'bad' banks, and thus it is likely that market confidence in the whole sector will suffer. ${ }^{85}$ The hypothesis that bank opacity increases sharply in times of crisis as banks avoid disclosing relevant information on their assets, has found strong empirical support in a recent study by Flannery et al. The study examined bank opacity over a 20 -year period and confirmed that during the recent financial crisis the opacity of bank assets increased to a level that is unique to the banking sector. ${ }^{86}$ This evidence provides formal support for the widespread view that the distrust among banks about the quality of their assets during the crisis indicates that 'even banks themselves find it difficult to assess the riskiness of other banks accurately'. ${ }^{87}$

1.44 Although it is uncontroversial to say that banks are generally much more opaque than generic companies in times of crisis, whether banks are always particularly opaque is an empirical question that has yet to be settled. A number of studies have failed to find any significant difference between banks and other companies in normal economic conditions. ${ }^{88}$ However, several other studies confirm that bank opacity is a pervasive feature of the sector at all times and not only in times of crisis. ${ }^{89}$ Each study uses a different methodology to measure

84 The study covers the period before the onset of the crisis. See M Cheng, D Dhaliwal and M Neamtiu, 'Banks' Asset securitisation and information opacity' (2008) University of Southern California Working Paper, available at: http://www.usc.edu/schools/business/FBE/seminars/papers/ARF_5-2-08_NEAMTIU.pdf, accessed 1 January 2014.

85 This is a type of market failure conventionally described as a 'market for lemons' whereby products of the lower quality prevail because of the inability of customers to distinguish between high- and low-quality products.

86 See M J Flannery, S H Kwan, and M Nimalendran, 'The 2007-09 financial crisis and bank opaqueness' (2010) Federal Reserve Bank of San Francisco Working Paper 2010-27, available at: http://www.frbsf.org/economicresearch/files/wp10-27bk.pdf, accessed 1 January 2014.

87 See Mulbert, above note 54, 11 .

88 See e.g. M J Flannery, S H Kwan, and M Nimalendran, 'Market evidence on the opaqueness of banking firms' assets' (2004) 71 Journal of Financial Economics 419; 'The 2007-09 financial crisis and bank opaqueness' see above $\mathrm{n} 86$.

89 Morgan found that credit rating agencies were more likely to disagree on the rating of bonds issued by banks than by other companies between 1983 and 1993. See D P Morgan, 'Rating banks: Risk and uncertainty in an opaque industry' (2002) 92 American Economic Review 874. The same was found with respect to European banks in the period 1993-2003 by Iannota. See G O Iannotta, 'Testing for opaqueness in the European banking industry: Evidence from bond credit ratings' (2006) 30 Journal of Financial Services Research 287. In addition, 
asset opacity (which cannot be observed directly) such as the disagreement amongst credit rating agencies on the rating of bonds issued by banks, ${ }^{90}$ and the likelihood of analysts' forecasts errors. On balance, the opacity of banks' assets is generally accepted by the relevant literature ${ }^{91}$ as one of the main components of bank specificity. From the perspective of the argument here, it is sufficient that available evidence supports the proposition that banks' assets are intrinsically opaque. It may be true that in normal economic conditions market confidence reduces the degree of disagreement between market players about the value of bank assets, and hence reduces observable opacity, ${ }^{92}$ but the sharp increase of observable opacity in times of crisis shows that bank assets are intrinsically difficult to value.

\section{ii. The effect of asset opacity on risk-monitoring by bank shareholders}

The opacity of banks' assets severely limits the effectiveness of market discipline of risk-taking by banks for the following reason. Since equity investors are not capable of assessing the real value of the assets in banks' balance sheets based on available information, the prices at which banks' shares trade does not reflect this, but rather mostly reflect the profits made by banks and the dividends paid. Indeed, there is evidence that in the years leading up to the recent financial crisis investors did not appreciate that the increased returns on bank equities were achieved by increasing leverage and taking on more risk. ${ }^{93}$ It follows that banks were not punished by a higher cost of capital as a result of increased risk-taking. In other words, increasing leverage and engaging in risky activities were virtually costless for banks. It is evident that in such conditions, the senior managers of large banks faced a powerful incentive to follow risky strategies in

Iannota and Navone found that between 1990 and 2000 US banks were more likely to suffer abrupt negative changes in their share prices (crashes) than other companies. See G Iannota and M A Navone, 'Crashes and bank opaqueness' (2009) Universita Luigi Bocconi CAREFIN Research Paper No. 20/09, available at: http://papers.ssrn.com/sol3/papers.cfm?abstract_id=1600190, accessed 1 January 2014. Consistent with the hypothesis that banks are more opaque than other companies are the findings of Haggard and Howe that the shares of banks incorporate less firm-specific information than other companies of similar characteristics. See K S Haggard and J S Howe, 'Are banks opaque?' (2007) University of Southern Mississippi Working Paper, available at: http://www.scribd.com/doc/156507098/Haggard-Stephen-K-John-S-Howe-2007-Are-BanksOpaque-Jan-11-41-Pp, accessed 1 January 2014.

90 The use of split credit ratings as a proxy for asset opacity has been criticised by Hauck and Neyer. See A Hauck and U Neyer, 'Are rating splits a useful indicator for the opacity of an industry?' (2008) Heinrich-HeineUniversity of Düsseldorf Economics Finance, and Taxation Discussion Paper No. 3/2008, available at: http://papers.ssrn.com/sol3/papers.cfm?abstract_id=2103169, accessed 1 January 2014.

91 See above $\mathrm{n} 80$.

92 Before the recent crisis market confidence in banks was also supported by the implied government support that large systemic institutions enjoyed.

93 From 2002 to 2007 large global banks raised their dividends on average by 15 per cent per annum. At the same time investors did not price correctly the greater risks taken by banks until the crisis began. On this, see M R King, 'The cost of equity for global banks: a CAPM perspective from 1990 to 2009' (2009) (September) BIS Quarterly Review 56, 70-71. 
order to earn the highest possible performance-based remuneration. Thus, far from acting as a constraint on risk-taking, the capital market facilitated a level of risk, ${ }^{94}$ which fully informed investors would not have sanctioned without demanding an appropriate risk premium. ${ }^{95}$

1.46 A connected problem is that, since the assets of banks cannot be accurately valued by the investors, senior managers can easily manipulate banks' financial results and hence manage their share prices. This enables them to reach targets set by their remuneration contracts and entrench themselves in their positions. At this point it is essential to clarify that the argument here does not suggest that senior managers of UK banks have been engaging in unlawful market abuse, which carries criminal and civil penalties. ${ }^{96}$ Rather, the point is that, given the asset opacity explored above, it can be expected that bank managers will tend to engage in borderline practices of managing financial announcements and strategically forming corporate policy in order to influence a bank's share price. Indeed, there is considerable empirical evidence that in the years leading up to the crisis banks (and other companies) resorted to securitisation at carefully selected points in time, when their earnings were low, to prevent a fall in their share prices. ${ }^{97}$ There is also strong evidence that banks can manage the

94 One additional way in which banks can take excessive risk is by expanding their assets via irresponsible lending. This was particularly easy in the early- to mid-2000s in part due to the favourable general market conditions and low interest rates.

95 Jones et al observed a feedback effect in the share prices of banks between 2000 and 2006. This means that risky banks were rewarded with higher equity values and hence other banks were encouraged to invest in risky and more opaque assets. See J S Jones, W W Lee and T J Yeager, 'Valuation and systemic risk consequences of bank opacity' (2013) 37 Journal of Banking E Finance 693.

96 The modern UK regime is based on EU law. Sections 52 and 53 of the Criminal Justice Act 1993 implemented the Insider Dealing Directive. See Council Directive 89/592/EEC of 13 November 1989 coordinating regulations on insider dealing [1989] OJ L334/30. Further amendments to the UK regulatory framework were introduced in compliance with the Market Abuse Directive (MAD), including new section 118 of the Financial Services and Market Act (FSMA) 2000, which identifies seven types of prohibited behaviour. See Directive 2003/6/EC of the European Parliament and of the Council of 28 January 2003 on insider dealing and market manipulation (market abuse) [2003] OJ L96/16. There are several English and European cases clarifying the test to be used, see e.g. Winterflood Securities Ltd v The Financial Services Authority [2010] EWCA Civ 423; Case C-45/08 Spector Photo Group NV and Chris Van Raemdonck v Commissie voor het Bank,-Financie-en Assurantiewezen (CBFA) [2010] OJ C-51/6. On the effect of MAD see J L Hansen, 'Insider dealing after the market abuse directive' in D Prentice and A Reisberg (eds) Corporate Finance in the UK and EU(OUP 2011).

97 See P M Dechow and C Shakespeare, 'Do managers time securitization transactions to obtain accounting benefits?' (2006), available at: http://papers.ssrn.com/sol3/papers.cfm?abstract_id=928741, accessed 1 January 2014. In addition, the same authors found that CEO pay sensitivity to securitizations is high thus allowing for a perverse incentive to manage the timing of the transactions. See P M Dechow, L A Myers and C Shakespeare, 'Fair value accounting and gains from asset securitizations: A convenient earnings management tool with compensation side-benefits' (2010) 49 Journal of Accounting and Economics 2. 
information content of their periodic financial disclosures and hence influence the price of their shares without being noticed by investors and analysts. ${ }^{98}$

Overall, the preceding discussion establishes that equity market discipline on risk-taking by banks is severely limited as potential equity investors cannot accurately value banks' assets and assess the risks taken by banks. This phenomenon enables bank senior managers to take excessive risks and manage the share price by appropriately tailoring financial disclosures and balance sheet restructurings. I therefore argue that in banks shareholder agency costs are higher than in non-financial companies. Taking into account the opacity of banks' assets discussed above, it is evident that it is more difficult for bank shareholders to monitor senior management and protect themselves against excessive risk taking.

\section{B. The limits of bondholder monitoring of risk taking by banks}

Generally, creditor governance is a substantial check on risk-taking by companies, as creditors demand higher interest rates to advance credit to companies that take higher risks. Covenants in loan facilities also serve a governance function in generic companies with regard to their business activities and risk profile. ${ }^{99}$ In the context of banks, it is necessary to distinguish between two main types of creditors, namely depositors and bondholders. Bonds are debt securities issued by banks that are traded on a regulated market. For regulatory purposes, it is common practice for bonds to be subordinated to the ordinary creditors of banks (depositors) so that they can serve as loss absorbing capital. Reference to bonds will thus imply subordinated bonds that rank after the claims of depositors. Depositors are the beneficiaries of bank accounts and their potential monitoring role will be explored in the following part.

Bondholders have a rational incentive to monitor risk-taking by banks and to demand higher interest rates to compensate for increased risk-taking. Indeed, bondholders' attitudes to risk is markedly different than that of the shareholders, as creditors risk losing their investment in the event of failure, but have nothing to gain if a bank does exceptionally well. Faith in bondholder governance is reinforced by the fact that investors in bonds are usually professional

98 In particular, a US study found that quarterly disclosure of impaired loans was only meaningful in quarters that banks were examined by regulators. See A Ashcraft and H Bleakley, 'On the market discipline of informationally opaque firms: Evidence from bank borrowers in the federal funds market' (2006) Federal Reserve Bank of New York Staff Report 257, available at: http://www.newyorkfed.org/research/staff_reports/sr257.html, accessed 1 January 2014.

99 In term loans to commercial companies banks typically include covenants that restrict the freedom of the borrower to change its business or enter into substantial transactions without the approval of the bank. 
funds with a reasonable level of expertise and a substantial investment size that allows for monitoring expenditure. Indeed, in recent years banks have been encouraged to use subordinated debt (bonds) as an additional tier of capital and it has been contemplated that market discipline would complement supervision by public authorities. ${ }^{100}$ In particular, if risk-taking by banks was accurately reflected in the interest rates they paid on bonds (and on the prices at which bonds trade on the secondary market), banks would be discouraged from taking excessive risks, and a clear signal would be given to regulators at once that a bank was perceived by the market as highly risky. ${ }^{101}$

1.50 However, the opacity of banks' assets limits the potential of the capital market to price accurately the bonds issued by banks and thus exposes bondholders to the same risk of managerial opportunism. The preceding analysis on bank opacity and the evidence examined in the previous section is also relevant from the perspective of bondholders. If the market cannot distinguish between more and less risky banks, then both shareholders and bondholders are unable to assess the riskiness of their investment and the return they demand will not reflect the level of risk taken by the issuing bank. In particular, as noted above, empirical studies on bank opacity confirm that in the case of bonds issued by banks credit rating agencies are more likely to disagree on their ratings than in bond issues by other companies. ${ }^{102}$

1.51 To be sure, I do not purport to claim that bond market discipline is obsolete in the case of banks. The bond market provides a degree of discipline and reflects available information on banks' riskiness. ${ }^{103}$ However, as explained in the previous section, information on the quality of bank assets is more difficult to process and verify, and banks tend to withhold relevant information in times of crisis. Bank opacity thus diminishes the disciplinary effect of the bond market especially with regard to bond issues where credit ratings agencies produce split ratings. ${ }^{104}$

100 The emphasis on market discipline until the crisis was reflected in Basel II. Currently, subordinated debt can qualify as Tier 2 capital. See Basel Committee on Banking Supervision, 'Basel III: A global regulatory framework for more resilient banks and banking systems' (Rev edn, 2011) para 58.

101 This is an example of enrolling private parties to perform regulatory functions as part of modern reflexive regulatory techniques. On this, see J Black, 'Paradoxes and failures: New governance techniques and the financial crisis' (2012) 75 MLR 1037.

102 See above paras 1.40-1.44. See also Morgan, above n 89.

103 See N Esho and others, 'Market discipline and subordinated debt of Australian banks' (2005) Australian Prudential Regulation Authority Working Paper, available at: http://www.apra.gov.au/AboutAPRA/ Research/Documents/Market-Discipline-and-Subordinated-Debt-of-Australian-Banks-October-2005.pdf, accessed 1 January 2014.

104 See D P Morgan and K J Stiroh, 'Bond market discipline of banks: Is the market tough enough?' (1999) Federal Reserve Bank of New York Staff Report 95/1999, 13-14, available at: http://www.newyorkfed.org/ research/staff_reports/sr95.html, accessed 1 January 2014. 
Furthermore, risk-monitoring by bondholders is weakened as a result of the 1.52 perception of an implied government guarantee in the case of bonds issued by large banks. ${ }^{105}$ Although bonds are not protected by deposit insurance schemes, the market may perceive very big banks as being 'too-big-to-fail' and thus expect that they will be rescued by the government if they face financial difficulties. Indeed, in the UK the government recapitalised and rescued the Royal Bank of Scotland and Lloyds Banking Group at a very high cost to UK taxpayers of approximately $£ 51 \mathrm{bn},{ }^{106}$ but - unlike shareholders - bondholders did not lose their investments.

Of course, forthcoming regulatory reforms at the EU level aim to restore market discipline on banks by ensuring that the private creditors of banks, especially bondholders, stand to lose their investment if a bank fails. In the UK, the Financial Services Act 2010, which amended the Financial Services and Markets Act 2000, has already introduced a requirement for regulated institutions to draft recovery and resolution plans, also known as living wills. ${ }^{107}$ Recovery plans aim to facilitate the rescue of the business of a troubled financial company as a going concern to avoid systemic contagion which may be triggered by a failure. Resolution plans aim to ensure an orderly winding-up in the event of failure in order to minimise systemic disruption. ${ }^{108}$ Recovery and resolution plans are to be evaluated by the PRA and, if found inadequate, the institution must take any appropriate steps to amend them. In parallel, a fourth stabilisation option, namely bail-in stabilisation, will shortly be added in the Banking Act 2009 framework as a result of the Financial Services (Banking Reform) Act 2013. 109

The forthcoming Recovery and Resolution Directive (RRD) ${ }^{110}$ will emphasise the use of debt capital as a means to absorb bank losses in advance of using public funds, thus implementing relevant international standards. ${ }^{111}$ It is

105 Ibid., 14-15.

106 On the cost of the recent crisis to the UK Government, see above para 1.22 and n 49.

107 Section 7 of the Financial Services Act 2010 introduces ss 139B-139F into FSMA 2000.

108 A discussion of the complex issues arising out of the resolution of systemic banks can be found in S Claessens, R J Herring and D Schoenmaker, 'A safer world financial system: Improving the resolution of systemic institutions' (Centre for Economic Policy Research, 2010).

109 Section 2 of Sch 2 to the Act will insert ss 12A and 12B into the Banking Act 2009 when it comes into force.

110 In December 2013 representatives of the European Parliament and Council reached prima facie agreement on a Recovery and Resolution Directive. The EU authorities intend the Directive to come into force on 1 January 2015 and the bail-in system to apply from 1 January 2016. See European Parliament News, 'Deal reached on bank bail-in directive' (12/12/2013), available at: http://www.europarl.europa.eu/news/en/news-room/ content/20131212IPR30702/html/Deal-reached-on-bank-\%E2\%80\%9Cbail-in-directive\%E2\%80\%9D, accessed 1 January 2014.

111 International resolution standards were drafted by the FSB and endorsed by G-20 leaders in 2011. See Financial Stability Board, 'Key attributes of effective resolution regimes for financial institutions' (2011), available at: https://www.financialstabilityboard.org/publications/r_111104cc.htm, accessed 1 April 2014. 
envisaged that at the stage of recovery any contingent convertible bonds banks have issued will be turned into equity. Then, at the resolution stage the bail-in procedure seeks to limit the extent of the use of public funds. ${ }^{112}$ The shareholders and bondholders will be the first to lose their investment before any public money is used to rescue the ailing bank, at least until 8 per cent of the bank's assets are lost. Conversely, depositors with funds in excess of $£ 85,000$ would be affected only after the use of the money available at the bank-funded resolution fund, which is expected to reach 1 per cent of covered deposits until 2025. These forthcoming reforms have already undermined the perception of an implied government guarantee on bonds issued by banks, and may in the future effectively tackle this aspect of the problem, ${ }^{113}$ but will still not affect the fundamental problem of bank asset opacity identified above.

1.55 To sum up, the preceding analysis shows why bondholders are not fully capable of monitoring risk-taking by banks, and are not in the same position as bank managers to access and process relevant information due to bank opacity. The wealth of bondholders, therefore, depends on bank managers, since bondholders cannot adequately protect themselves by contract. It can be argued thus that the interest rates paid by the banks on their bonds do not adequately reflect their risk profile. ${ }^{114} \mathrm{~A}$ principal-agent relationship between bondholders and bank managers can therefore be established. ${ }^{115}$

\section{The very limited risk-monitoring by depositors}

1.56 The depositors of UK banks cannot be relied on to perform an effective risk-monitoring function because of the combined effect of three factors. First, depositors lack the necessary expertise to process relevant information on the level of risk taken by banks. Retail depositors, especially, are in a very weak

112 On the future implementation of bail-ins in the UK, see the speech given by the director of the Special Resolution Unit of the Bank of England: A Gracie, 'A practical process for implementing a bail-in resolution power' (British Bankers' Association, London, 17 September 2012), available at: http://www.bankof england.co.uk/publications/Documents/speeches/2012/speech600.pdf, accessed 1 April 2014.

113 A critical discussion of special resolution regimes can be found in C Hadjiemmanuil, 'Special resolution regimes for banking institutions: Objectives and limitations' in W-G Ringe and P M Huber (eds), Legal Challenges in the Global Financial Crisis (Hart Publishing 2014). Hadjiemmanuil highlights the inconsistency between: on the one hand the policy objective of reducing moral hazard by ensuring that shareholders and debtholders suffer losses; and, on the other, the objective of reducing contagion when a crisis occurs, which militates against imposing losses to debtholders as doing so undermines investor confidence in other banks within the same financial system.

114 Bank creditors can thus be said to have incomplete contract, like shareholders. The concept of incomplete contracts was introduced by Williamson. See O E Williamson, Markets and Hierarchies: Analysis and Antitrust Implications: A Study in the Economics of Internal Organization (Collier Macmillan 1975).

115 On the role of bondholders, see also K J Hopt, 'Corporate governance of banks after the financial crisis' in E Wymeersch, KJ Hopt and G Ferranini (eds), Financial Regulation and Supervision: A post-crisis analysis (OUP 2012). 
position to process relevant information as they are unsophisticated individuals who lack an adequate understanding of the banking sector and of financial reporting. ${ }^{116}$ Large companies are in a slightly better position than individuals and small businesses, but still evaluating the creditworthiness of a bank falls outside the ability of most corporate officers. In addition, companies seek to raise loans from banks, and hence the willingness of banks to advance credit is the major determinant of their choice of the main bank of a company, rather than the assessment of the bank's soundness.

Second, depositors are in a relatively weak bargaining position vis-à-vis banks and therefore it is difficult for them to demand a higher interest rate if they think that a bank is more risky. The retail banking market in the UK is oligopolistic and despite fierce competition to attract depositors the practical difficulties of moving one's accounts from one bank to another, combined with the feeling of loyalty that many depositors have for their banks raises an additional obstacle to the operation of market discipline. ${ }^{117}$ Creditor self-help measures such as adjusting the interest rates, demanding security, drafting appropriate covenants and monitoring debtors work well for banks as the major creditors of businesses and individuals, but are not available to depositors who are unsecured, inexpert and relatively badly resourced.

The third and most decisive factor that neutralises depositor monitoring is deposit insurance by the UK Financial Services Compensation Scheme. ${ }^{118}$ Given the immunity of most depositors from bank failures, it follows that their incentives to monitor banks are very weak, especially if it is taken into account that processing the relevant information is costly and time consuming. Even depositors who hold large deposits can still structure their portfolio so as to be fully covered, as the maximum limit of $£ 85,000$ applies to accounts held with each separately licensed banking group. In addition, given that depositors need

116 A review of the literature on the inability of depositors to monitor banks and its implications can be found in J A C Santos, 'Bank capital regulation in contemporary banking theory: A review of the literature' (2001) 10 Financial Markets, Institutions $\mathcal{E}^{\circ}$ Instruments 41, 46-52.

117 On this, see Treasury Committee, 'Competition and choice in retail banking' (HC 2010-11, 612-I). The report finds that the retail banking market is particularly concentrated as more than 90 per cent of current accounts are held with the five largest banks (para 47). Although market concentration does not necessarily indicate limited competition, the committee considered that - on the balance of evidence - competition in the retail banking market is limited (paras 49-50).

118 Since 31 December 2010, the coverage limit has been raised to the equivalent in pounds of $€ 100,000$ i.e. $£ 85,000$ in compliance with EU law. See Directive 2009/14/EC of the European Parliament and of the Council of 11 March 2009 amending Directive 94/19/EC on deposit-guarantee schemes as regards the coverage level and the pay-out delay, Article 1. The amount is payable in full for each account (or set of accounts) or other eligible non-equity investment in a separately licensed bank to natural persons and small companies. Until December 2010 the coverage limit was $£ 50,000$ and until October 2008 it was $£ 35,000$. It is interesting to note that until October 2007 depositors could only claim 90 per cent of the sum between $£ 2,000$ and $£ 35,000$ so the maximum payoff could reach $£ 31,700$. 
not worry about the creditworthiness of banks, they face a perverse incentive to place their funds with riskier banks which can pay higher interest rates (as they are more profitable), rather than with prudent banks. It follows that far from acting as a constraint on risk taking, market pressures in this context actually encourage increased risk taking as a means to attract depositors.

1.59 The inability of depositors to monitor risk-taking by banks would seem to support the finding that they are susceptible to suffering managerial agency costs, similarly to bondholders. However, deposit protection and government intervention insulates (most) depositors from managerial agency costs and transfers these costs to the public. It follows that while bondholders stand to bear the costs of managerial opportunism directly, depositors are protected from bank failures and, instead, it is the taxpayers who stand to suffer from excessive risk-taking in the banking sector.

\section{THE EFFECT OF BANK OPACITY ON THE CORE PROBLEM OF THE MISALIGNMENT BETWEEN THE PUBLIC INTEREST AND CONVENTIONAL CORPORATE GOVERNANCE}

1.60 Bringing together the findings of Section 3 on the externalities caused by running banks with a view to profit maximisation and of the present section, it must be emphasised that the argument advanced in that section does not depend on the finding here that banks are more opaque than other companies. One may therefore inquire what does the previous evidence on the limited ability of bank shareholders and creditors to monitor risk-taking add to the chapter. I will seek to explain that bank opacity and the absence of effective risk monitoring is relevant from the perspective of the problem of externalities in a number of ways.

1.61 First, bank opacity serves to explain the persistence of systemic risk that affects the banking industry. ${ }^{119}$ One of the main reasons that the failure of one major institution is likely to undermine the soundness of other institutions is that since banks are opaque, both equity and debt investors cannot distinguish between sound and problematic banks. As a result, at times of crisis they lose their confidence in the banking system as a whole thus prompting depositors' runs, liquidity shortages and making it difficult for banks to raise additional share capital during a crisis. 
Second, the finding that risk-monitoring by bank shareholders and creditors is ineffective demonstrates that the misalignment identified in Section 3 is a very serious one. Even if market discipline ensured that equity and debt providers were fully compensated for the risk taken by banks, systemic risk ${ }^{120}$ would still lead to bank failures causing negative externalities on the shareholders and creditors of other banks. However, the limited ability of bank shareholders and creditors to restrain risk-taking by bank managers, combined with the incentives the latter face to take excessive risks, means that banks take more risk than fully informed investors would accept. It follows that the profit maximisation norm leads to the assumption of a level of risk that is excessive even from the perspective of banks' shareholders and creditors and is far higher than the level of risk that is socially desirable. Indeed, as shown in the following section, the bank failures that caused the recent financial crisis can be partly attributed to excessive risk-taking encouraged by the urge to maximise short-term profitability. In this sense, bank opacity strengthens the finding of Section 3 that the current corporate governance regime undermines financial stability. ${ }^{121}$

Third, the deep-rooted causes of bank opacity that go beyond the availability of 1.63 information and include the inability of investors to process relevant information suggest that the misalignment between the current corporate governance paradigm and financial stability cannot be effectively tackled by reinforcing market discipline. The previous analysis shows that the introduction of further regulatory requirements to disclose more information ${ }^{122}$ would be unlikely to materially increase the risk monitoring potential of bank shareholders and bondholders. ${ }^{123}$ It follows that reliance on market discipline to alleviate the financial stability consequences of risk-taking and profit-seeking by banks is misguided and unlikely to achieve its purpose. This finding supports the need for a direct regulatory approach to tackle this problem. ${ }^{124}$

120 It should be kept in mind that opacity is not the only cause of systemic risk and hence it would exist even if banks were no more opaque than other companies.

121 Even authors who argue that market-based corporate governance mechanisms operated well during the recent crisis, accept that in the case of banks there have been corporate governance failures. See e.g. B R Cheffins, 'Did corporate governance "fail" during the 2008 Stock Market meltdown? The case of the S\&P 500' (2009) ECGI Law Working Paper No. 124/2009, available at: http://papers.ssrn.com/sol3/papers.cfm?abstract_id= 1396126, accessed 1 January 2014.

122 Existing requirements are set out in Regulation (EU) No 575/2013 of the European Parliament and of the Council of 26 June 2013 on prudential requirements for credit institutions and investment firms and amending Regulation (EU) No 648/2012 [2013] OJ L176/1, arts 431-455.

123 On this see E Avgouleas, 'The global financial crisis and the disclosure paradigm in European financial regulation: The case for reform' (2009) 6 European Company and Financial Law Review 440.

124 Another complication is caused by the fact that increased transparency of bank assets, even if feasible, can potentially undermine financial stability if a number of large banks have suffered losses. In this sense, it is arguable that bank opacity is a threat to financial stability because of its ex ante effects on market discipline, but simultaneously transparency can threaten financial stability ex post when a crisis is on the verge of erupting. 
1.64 Fourth, the finding that the current regime, although apparently focused on shareholder value maximisation, does not actually lead to this outcome, as it allows a level of risk-taking that is excessive for bank shareholders and creditors, further supports the case for regulating risk-taking by banks, as it defeats the potential objection that regulation is value decreasing for bank shareholders. Regulating risk-taking by banks would benefit shareholders by preventing senior managers from taking risks that are excessive from the shareholders' point of view, but would come at the cost of leading to a level of risk that is lower than the one preferred by perfectly informed and co-ordinating shareholders.

\section{TOWARDS A REGULATORY APPROACH TO BANK CORPORATE GOVERNANCE}

1.65 The preceding analysis suggests that a regulatory approach to bank corporate governance, as a complement to tougher capital standards and better crisis management tools, is the best available option to reform the area. Indeed, the vital importance of bank corporate governance reforms has become widely accepted in policy-making and regulatory circles in recent years and a number of reform initiatives in the UK and EU have already radically changed the landscape of bank corporate governance, as will be illustrated in the following paragraphs. Still, these reforms fall short of fundamentally changing the existing shareholder-centric and facilitative nature of bank corporate governance and therefore further reform is necessary.

\section{A. The recent regulatory interventions to bank corporate governance}

1.66 An integral part of the international regulatory response to the recent financial crisis was a series of reforms in bank corporate governance beginning with the publication of the Principles for Enhancing Corporate Governance in late $2010 .{ }^{125}$ Although significant in achieving a degree of international convergence in the area, the recommendations did not add much to the UK bank corporate governance regime, as most of these requirements were already in place here, subsequent to the Walker Review Recommendations and the latest revision of the UK Corporate Governance Code. The Principles focus on effective boards, sound risk management, executive remuneration, the simplification of group structures and transparency. They are modelled on the OECD

125 See Working Group on Corporate Governance of the Basel Committee, Principles for Enhancing Corporate Governance (Nouy Daniele et al, Bank of International Settlements 2010). 
Principles of Corporate Governance ${ }^{126}$ which apply generally to listed companies. Indeed, apart from their emphasis on risk management evinced in the requirements for a board risk committee, a Chief Risk Officer and the scrutiny of new products and mergers, the Basel Principles do not differentiate bank corporate governance from the governance of ordinary non-financial companies.

From the point of view of this chapter, the most notable contribution of the

Principles is that they illustrate the attitude of major regulators worldwide on bank corporate governance. First, it is acknowledged that corporate governance is 'of great relevance'127 both at the micro-level of individual banks and at the macro-level of the stability of financial systems, since it can provide proper incentives to bank controllers, facilitate supervision and foster market confidence. Secondly, the recent crisis is seen as partly due to governance failures, since poor governance is liable to lead both to individual banks' failures and to wider problems, due to the loss of confidence in the financial markets. ${ }^{128}$ Thirdly, great emphasis is placed on the role of supervisors ${ }^{129}$ who are expected to evaluate the corporate governance structures of individual banks, including the expertise and integrity of prospective directors and senior managers, and to have formal powers to take remedial action, should the governance of a bank be judged to be defective.

Perhaps the most striking example of the incipient regulatory encroachment of bank corporate governance is the regulation of the structure of senior executive remuneration under the CRD IV framework. ${ }^{130}$ Broadly speaking, variable pay cannot exceed 100 per cent of fixed remuneration, ${ }^{131}$ unless the shareholders of a bank approve a higher rate, which cannot exceed 200 per cent of fixed remuneration. ${ }^{132}$ In parallel, the Directive allows Member States to allow banks

126 The Principles were last revised in April 2004 and are at the time of writing under review. See Organisation for Economic Co-operation and Development, 'OECD Principles of Corporate Governance' (2004), available at: http://www.oecd.org/corporate/oecdprinciplesofcorporategovernance.htm, accessed 1 April 2014.

127 See Principles for enhancing corporate governance, see above n 125, 1-2.

128 Ibid., 5.

129 Ibid., 30-32.

130 A critical evaluation of the impact of CRD IV on bank corporate governance can be found in J Winter, 'The financial crisis: Does good corporate governance matter and how to achieve it?' in Wymeersch, Hopt and Ferranini (eds), Financial Regulation and Supervision, see above n 115, especially paras 12.19-12.33.

131 See CRD IV, art 94(1)(g)(i) and PRA Handbook SYSC 19A.3.44.

132 See CRD IV, art 94(1)(g)(ii) and PRA Handbook SYSC 19A.3.44A-C. The procedure to be followed for shareholders to approve a higher variable component (up to 200 per cent of fixed pay) is the following: all shareholders must be given a reasonable notice period in advance of the relevant meeting and must be provided with a detailed statement by the institution on the impact of the proposed increase of variable pay on the bank's ability to maintain a sound capital base. In addition, the resolution approving the increase must be passed by at least 66 per cent of the share capital provided that at least 50 per cent of the shares are represented at the 
to apply a discount rate to up to 25 per cent of total variable remuneration ${ }^{133}$ provided that it is paid in instruments that are deferred for at least five years in accordance with guidelines to be published by the EBA. The draft guidelines published by the EBA take into account four factors to calculate the discount rate, namely the national inflation rate, the average interest rate paid on $\mathrm{EU}$ sovereign bonds, the length of the deferral period and any additional retention period requirement. ${ }^{134}$

1.69 In addition, CRD IV introduced several mandatory rules regulating the structure of bank boards. The Directive's approach to the functioning of bank boards is based on the uncontroversial acceptance of five general principles, namely: sufficient collective knowledge; time commitment; adequate resources; diversity; and honesty. ${ }^{135}$ Crucially, CRD IV precludes banks from combining the positions of $\mathrm{CEO}$ and chairman of the board without the consent of the regulator, ${ }^{136}$ and requires nomination committees to consist exclusively of non-executive directors. ${ }^{137}$ Although these requirements coincide with the existing recommendations of the Corporate Governance Code ${ }^{138}$ and - to a large extent - with the actual practice of UK banks, ${ }^{139}$ the juridification of the relevant rules from comply-or-explain soft law (enforceable via market pressure) to regulatory standards is noticeable. Furthermore, CRD IV imposes a cap on parallel board appointments to the effect that the same person cannot hold more than: either one executive and two non-executive appointments; or four non-executive appointments. ${ }^{140}$ Appointments at non-for-profit organisations and charities are excluded from the cap, ${ }^{141}$ and competent regulators are given the discretion to allow bank directors to hold one additional non-executive position. ${ }^{142}$

1.70 In parallel, the recent Financial Services (Banking Reform) Act 2013 will - as soon as fully implemented - overhaul the approved persons' regime for bank

meeting, or by 75 per cent of the share capital. Any shareholders who are affected by the decision (e.g. directors or managers of the bank) are disqualified from voting.

133 CRD IV, article 94 (1) (g) (iii) and PRA Handbook SYSC 19A.3.44D.

134 See EBA, 'Draft Guidelines on the applicable notional discount rate for variable remuneration under Article 94(1)(g)(iii) of Directive 2013/36/EU' (2013) EBA/CP/2013/40.

135 See CRD IV, art 91(1), (2) and (7)-(9).

136 CRD IV, art 88(1)(e).

137 CRD IV, art 88(2).

138 See UK Corporate Governance Code, paras A.2.1 and B.2.1 respectively.

139 All major UK banks operate fully independent nominations committees, and have a separate board chairman and $\mathrm{CEO}$, although board chairmen are not always independent, the most notable example being the case of HSBC.

140 The cap will be effective on 1 July 2014. See CRD IV, art 91(3).

141 CRD IV, art 91(5).

142 CRD IV, art 91(6). 
directors. ${ }^{143}$ Traditionally, UK regulatory authorities took a light-hand approach towards the 'fit and proper' test for bank directors and senior managers and generally relied on banks' judgement for the suitability of key persons, and only focused on the honesty and integrity of proposed candidates. This approach started to change subsequent to the recent crisis, when regulators adopted a more inquisitive and pro-active stance emphasising the competence of proposed bank directors as much as their honesty. ${ }^{144}$ The recent legislative change will further reinforce the substantial role of regulators in ensuring that bank boards are appropriately structured and composed thus marking the departure from the orthodox market-based approach to corporate governance.

\section{B. A broader reconceptualisation of bank corporate governance}

Despite these reforms, the shareholder-centric character of bank corporate governance persists through the substantial remaining components of variable remuneration, the pressures from the market for corporate control and institutional shareholders, and the application of directors' duties on banks in the same manner as in generic companies. In the same vein, most scholars still perceive bank corporate governance as synonymous to an exercise of aligning the interests of senior managers to the interests of dispersed shareholders, ${ }^{145}$ thus obfuscating the potential complementarity between a regulatory approach to corporate governance and other aspects of prudential regulation.

The argument here is that it is necessary to revisit the theoretical understanding of bank corporate governance under the prism of a regulatory approach as a necessary prerequisite to the successful implementation of existing bank corporate governance reforms and to the future development of the area. Indeed, a regulatory model of bank corporate governance would serve as a clear theoretical basis and practical guide for regulators to discharge their new functions on executive remuneration and the approved persons' regime. Furthermore, it would serve as the basis for a radical reform of banks' corporate objective and directors' duties to reflect the change of focus from profit maximisation to entity preservation.

143 Part 4 of the Act will amend the FSMA 2000 (ss 18-35) and introduce a new criminal offence for bank senior managers (ss 36-38).

144 A detailed discussion of the evolution of the fit and proper test until early 2012 can be found in A Kokkinis, 'The reformed "fit and proper" test: A call for a broader rethink of bank corporate governance?' (2012) 9 ICR 5.

145 For instance, White reviews the interplay between corporate governance and financial regulation and assumes that corporate governance necessarily aims to protect the interest of the shareholders. He thus concludes the achievement of regulatory objectives requires a worsening of bank corporate governance. See L J White, 'Corporate governance and prudential regulation of banks: is there any connection?' in J R Barth, C Lin and C Wihlborg (eds), Research Handbook on International Banking and Governance (Edward Elgar 2012). 
1.73 The main characteristics of a regulatory approach to bank corporate governance would be the change of focus from serving the private interests of shareholders to protecting the public interest in financial stability, and the abandonment of reliance on shareholders and market discipline in favour of regulatory supervision of governance structures. Since the unqualified pursuit of profit is incompatible with safeguarding financial stability, it follows that a regulatory approach would have to lexically prioritise the preservation of financial stability in the public interest over the maximisation of profits for the benefit of banks' shareholders.

\section{CONCLUSION}

1.74 This chapter sought to provide an overview of the corporate governance problems faced by banks. In doing so, the discussion focused on several widely accepted economic characteristics of banks, which are unique to the sector, especially the extremely high leverage, systemic risk, and the crucial importance of the sector to the economy as a whole, and the opacity of banks' assets.

1.75 The main finding is that running banks with a view to profit maximisation under the current private ordering corporate governance paradigm creates negative externalities in the form of undermining financial stability. In parallel, the opacity of banks limits the ability of bank shareholders and bondholders to monitor risk taking by banks and thus exacerbates the above problem and suggests that reliance on market discipline cannot effectively respond to it. It follows that shareholder empowerment, which is a conventional remedy to corporate governance problems, can actually have negative consequences on the resilience of the financial system.

1.76 Therefore, the analysis here supports a radical change of approach to bank corporate governance from the current facilitative market-based approach, which focuses on shareholder value maximisation, to a regulatory approach which would focus on safeguarding financial stability. Indeed, a series of recent bank corporate governance reforms, both at the UK and EU levels, manifest the increased regulatory intervention in bank corporate governance subsequent to the recent financial crisis. Still, a broader reconceptualisation of bank corporate governance including their corporate objective and directors' duties is necessary as the basis for the future development of the regulation of bank corporate governance. 


\section{SELECTED BIBLIOGRAPHY}

Allen, F and A M Santomero, 'What do financial intermediaries do?' (2001) 25 Journal of Banking and Finance 271.

Allen, L and S A Cebenoyan, 'Bank acquisitions and ownership structure: Theory and evidence' (1991) 15 Journal of Banking and Finance 425.

Ashcraft, A and H Bleakley, 'On the market discipline of informationally opaque firms: Evidence from bank borrowers in the federal funds market' (2006) Federal Reserve Bank of New York Staff Report 257, available at: http://www.newyorkfed.org/research/staff_reports/sr257.html, accessed 1 April 2014.

Atkeson, A and W E Simon Jr, 'The rising fear in bank stock prices', The Wall Street Journal (28 November 2011), available at: http://online.wsj.com/news/articles/SB10001424052970 204531404577052493270860130 , accessed 1 January 2014.

Avgouleas, E, 'The global financial crisis and the disclosure paradigm in European financial regulation: The case for reform' (2009) 6 European Company and Financial Law Review 440.

Bainbridge, S M, 'Director primacy and shareholder disempowerment' (2006) 119 Harv L Rev 1735.

Ball, R, 'The global financial crisis and the efficient markets hypothesis: What have we learned?' (2009) 21 Journal of Applied Corporate Finance 8.

Basel Committee on Banking Supervision, 'Basel III: A global regulatory framework for more resilient banks and banking systems' (Rev edn, 2011).

Bebchuk, L A, Fried, M Jesse, and D Walker, 'Managerial power and rent extraction in the design of executive compensation' (2002) 69 U Chi L Rev 751.

Bebchuk, L A, A Cohen and H Spamann, 'The wages of failure: Executive compensation at Bear Sterns and Lehman 2000-2008' (2010) 27 Yale Journal of Regulation 257.

Berle, A A and G C Means, The Modern Corporation and Private Property (rev. edn, Harcourt, Brace \& World 1967).

BIS, 'A long-term focus for corporate Britain: A call for evidence' (2010), available at: https:// www.gov.uk/government/consultations/a-long-term-focus-for-corporate-britain-a-call-forevidence, accessed 1 January 2014.

Black, B S, 'Agents watching agents: The promise of institutional investor Voice', (1991-1992) 39 UCLA L Rev 811.

Black, B S, and J C Coffee Jr, 'Hail Britannia? Institutional investor behavior under limited regulation' (1993-1994) 92 Mich L Rev 1997.

Black, J, 'Paradoxes and failures: New governance techniques and the financial Crisis' (2012) 75 MLR 1037.

Caprio, G Jr., L Laeven and R Levine, 'Governance and bank valuation' (2003) World Bank Working Paper No. 3202, available at: http://papers.ssrn.com/sol3/papers.cfm?abstract_id= 463240, accessed 1 January 2014.

Castanias, R, 'Bankruptcy risk and optimal capital structure' (1983) 38 The Journal of Finance 1617.

Cheffins, B R, 'Did corporate governance "fail” during the 2008 Stock Market meltdown? The case of the S\&P 500' (2009) ECGI Working Paper No. 124/2009, available at: http:// papers.ssrn.com/sol3/papers.cfm?abstract_id=1396126, accessed 1 January 2014.

Cheffins, B R, 'The Stewardship's Code Achilles Heel' (2010) 73 MLR 1004.

Cheng, M, D Dhaliwal and M Neamtiu, 'Banks' asset securitisation and information opacity' (2008) University of Southern California Working Paper, available at: http://www.usc.edu/ schools/business/FBE/seminars/papers/ARF_5-2-08_NEAMTIU.pdf, accessed 1 January 2014. 
Ciancanelli, P, and J A Reyes-Gonzalez, 'Corporate governance in banking: A conceptual framework' (European Financial Management Association conference, Athens, June 2000), available at: http://ssrn.com/abstract=253714, accessed 1 January 2014.

Claessens, S, R J Herring and D Schoenmaker, 'A safer world financial system: Improving the resolution of systemic institutions' (Centre for Economic Policy Research, 2010).

Copp, S F, 'Section 172 of the Companies Act 2006 fails People and Planet' (2010) 31 Comp Law 406.

Crawford A J, J R Ezzell and J A Miles, 'Bank CEO pay-performance regulations and the effects of deregulation' (1995) 68 Journal of Business 231.

DeAngelo, H, and R M Stulz, 'Why high leverage is optimal for banks' (2013) Fisher College of Business Working Paper 2013-03-08, available at: http://papers.ssrn.com/sol3/papers. cfm?abstract_id=2254998, accessed 1 January 2014.

Dechow, P M, and C Shakespeare, 'Do managers time securitization transactions to obtain accounting benefits?' (2006), available at: http://papers.ssrn.com/sol3/papers.cfm?abstract_id= 928741, accessed 1 January 2014.

Dechow, P M, L A Myers and C Shakespeare, 'Fair value accounting and gains from asset securitizations: A convenient earnings management tool with compensation side-benefits' (2010) 49 Journal of Accounting and Economics 2.

DeYoung, R, E Y Pen, and M Yan, 'Executive compensation and business policy choices at U.S. commercial banks' (2013) 48 Journal of Financial and Quantitative Analysis 165.

Easterbrook, F H, and D R Fischel, The Economic Structure of Corporate Law (Harvard University Press 1991).

Elton, E J et al., Modern Portfolio Theory and Investment Analysis (8th edn, John Wiley \& Sons Inc. 2010).

Erkens, D H, M Hun, and P Matos 'Corporate governance in the 2007-2008 financial crisis: Evidence from financial institutions worldwide' (2012) 18 Journal of Corporate Finance 389.

Esho, N and others, 'Market discipline and subordinated debt of Australian Banks' (2005) Australian Prudential Regulation Authority (APRA) Working Paper, available at: http://www. apra.gov.au/AboutAPRA/Research/Documents/Market-Discipline-and-Subordinated-Debtof-Australian-Banks-October-2005.pdf, accessed 1 January 2014.

European Commission, Green Paper, 'Corporate governance in financial institutions and remuneration policies' COM (2010) 284 final.

European Parliament News, 'Deal reached on bank bail-in directive' (12/12/2013), available at: http://www.europarl.europa.eu/news/en/news-room/content/20131212IPR30702/html/

Deal-reached-on-bank-\%E2\%80\%9Cbail-in-directive\%E2\%80\%9D, accessed 1 January 2014.

Fama, E, 'Efficient capital markets: A review of theory and empirical work' (1970) 25 The Journal of Finance 383.

Financial Stability Board, 'Key attributes of effective resolution regimes for Financial institutions' (2011), available at: https://www.financialstabilityboard.org/publications/r_111104cc.htm, accessed 1 April 2014.

Flannery, M J, S H Kwan, and M Nimalendran, 'Market evidence on the opaqueness of banking firms' assets' (2004) 71 Journal of Financial Economics 419.

Flannery, M J, S H Kwan and M Nimalendran, 'The 2007-09 financial crisis and bank opaqueness' (2010) Federal Reserve Bank of San Francisco Working Paper 2010-27, available at: http://www.frbsf.org/economic-research/files/wp10-27bk.pdf, accessed 1 January 2014.

Gulinello, C, 'The retail investor vote: Mobilizing rationally apathetic Shareholders to preserve or challenge the board's presumption of authority' (2010) 3 Utah Law Review 547.

Hadjiemmanuil, C, 'Special resolution regimes for banking institutions: Objectives and limitations' in W-G Ringe and P M Huber (eds), Legal Challenges in the Global Financial Crisis (Hart Publishing 2014). 
Haggard, K S and J S Howe, 'Are banks opaque?' (2007) University of Southern Mississippi Working Paper, available at: http://www.scribd.com/doc/156507098/Haggard-Stephen-KJohn-S-Howe-2007-Are-Banks-Opaque-Jan-11-41-Pp, accessed 1 January 2014.

Hansen, J L, 'Insider dealing after the market abuse directive' in D Prentice and A Reisberg (eds) Corporate Finance in the UK and EU(OUP 2011).

Hauck, A and U Neyer, 'Are rating splits a useful indicator for the opacity of an industry?' (2008) Heinrich-Heine-University of Düsseldorf Economics Finance, and Taxation Discussion Paper No. 3/2008, available at: http://papers.ssrn.com/sol3/papers.cfm?abstract_id=2103169, accessed 1 January 2014.

Heremans, D, 'Corporate governance issues for banks. A financial stability perspective' (2007) University of Leuven Working Paper, available at: http://ssrn.com/abstract=1024693, accessed 1 January 2014.

Hopt, K J, 'Corporate governance of banks after the financial crisis' in E Wymeersch, K J Hopt and G Ferranini (eds), Financial Regulation and Supervision: A post-crisis analysis (OUP 2012).

Howson, N C, 'When "good" corporate governance makes "bad" (financial) firms: The global crisis and the limits of private law' (2009) 108 Mich L Rev (First Impressions) 44.

Iannota, G and M A Navone, 'Crashes and bank opaqueness' (2009) University Luigi Bocconi CAREFIN Research Paper No. 20/09, available at: http://papers.ssrn.com/sol3/papers. cfm?abstract_id=1600190, accessed 1 January 2014.

Iannotta, G O, 'Testing for opaqueness in the European banking industry: Evidence from bond credit ratings' (2006) 30 Journal of Financial Services Research 287.

Independent Commission on Banking, 'Final Report: Recommendations' (2011), available at: http://webarchive.nationalarchives.gov.uk/+/bankingcommission.independent.gov.uk, accessed 1 January 2014.

Jensen, M C and K J Murphy, 'CEO incentives - It's not how much you pay, but how' (1990) (May-June) Harvard Business Review 138.

Jensen, M C, and W H Meckling, 'Theory of the firm: Managerial behavior, agency costs and ownership structure' (1976) 3 Journal of Financial Economics 305.

Jensen, M C, K J Murphy and E G Wruck, 'Remuneration: Where we've been, how we got to here, what are the problems, and how to fix them' (2004) Harvard Business School Research Paper No. 04-28, available at: http://ssrn.com/abstract=561305, accessed 1 January 2014.

Jones, J S, W Y Lee and T J Yeager, 'Valuation and systemic risk consequences of bank opacity' (2013) 37 Journal of Banking and Finance 693.

Jones, J S, W Y Lee, T J Yeager, 'Opaque banks, price discovery, and financial instability' (2012) 21 Journal of Financial Intermediation 383.

Kay, J, 'The Kay Review of UK equity markets and long-term decision making - Final Report' (2012), available at: https://www.gov.uk/government/news/kay-review-publishes-report-onuk-financial-sector, accessed 1 January 2014.

Kershaw, D, 'Waiting for Enron: The unstable equilibrium of auditor independence regulation' (2006) 33 Journal of Law and Society 388.

King, M R, 'The cost of equity for global banks: a CAPM perspective from 1990 to 2009' (2009) (September) BIS Quarterly Review 56.

Kokkinis, A, 'The Financial Services Act 2012: The recent overhaul of the United Kingdom's financial regulatory structure' (2013) 24(9) ICCLR 325.

Kokkinis, A, 'The reformed "fit and proper" test: A call for a broader rethink of bank corporate governance?’ (2012) 9 ICR 5.

Kokkinis, Andreas, 'Rethinking banking prudential regulation: Why corporate governance rules matter?' (2012) 7 JBL 612.

Levine, R, 'The corporate governance of banks: A concise discussion of concepts and evidence' (2004) World Bank Policy Research Working Paper 3404, available at: http://elibrary. worldbank.org/doi/book/10.1596/1813-9450-3404, accessed 1 January 2014. 
Macey,J R, and M O’Hara, 'The corporate governance of banks' (2003) 9 Federal Reserve Bank of New York Economic Policy Review 91.

Manne, H G, 'Mergers and the market for corporate control' (1965) 73 The Journal of Political Economy 110.

Moore, M T, 'The evolving contours of the board's risk management function in UK corporate governance' (2010) 10 J Corp L Stud 279.

Moore, M T, Corporate Governance in the Shadow of the State (Hart Publishing 2013).

Morgan, D P, 'Rating banks: Risk and uncertainty in an opaque industry' (2002) 92 American Economic Review 874.

Morgan, D P, and K J Stiroh, 'Bond market discipline of banks: Is the market tough enough?' (1999) Federal Reserve Bank of New York Staff Report 95/1999, 13-14, available at: http://www.newyorkfed.org/research/staff_reports/sr95.html, accessed 1 January 2014.

Morgan, D P, and KJ Stiroh, 'Bond market discipline of banks: The asset test' (2001) 20 Journal of Financial Services Research 195.

Mulbert, P, 'Corporate governance of banks after the financial crisis: Theory, evidence, reforms' (2010) ECGI Working Paper No. 151/2010, available at: http://papers.ssrn.com/sol3/ papers.cfm?abstract_id=1448118, accessed 1 January 2014.

Organisation for Economic Co-operation and Development, 'OECD Principles of Corporate Governance' (2004), available at: http://www.oecd.org/corporate/oecdprinciplesofcorporate governance.htm, accessed 1 April 2014.

Osili, U O, and A Paulson, 'Bank crises and investor confidence: An Empirical investigation' (2008) Federal Reserve Bank of Chicago Working Paper No. 2008-17, available at: http:// www.chicagofed.org/webpages/publications/policy_discussion_papers/2009/pdp_9.cfm, accessed 1 January 2014.

Parliamentary Commission on Banking Standards, Changing banking for good (2013-14, HL 27-II, HC 175-II).

Policy Exchange, Ring fencing UK Banks: More of a problem than a solution (James Barty ed, Heron, Dawson and Sawyer 2013).

Polo, A, 'The corporate governance of banks: The current state of the debate' (2007) http:// ssrn.com/abstract=958796 accessed 1 January 2014.

Prowse, S D, 'Alternative methods of corporate control in commercial banks' (1995) Federal Reserve Bank of Dallas Economic and Financial Policy Review 3.

Prowse, S D, 'The corporate governance system in banking: What do we know?'(1997) (March) Banca del Lavoro Quarterly Review 11.

Rawlings, Philip, 'Bank Reform in the UK: Part II - Return to the Dark Ages?' (2011) 8 ICR 55.

Santos, J A C, 'Bank capital regulation in contemporary banking theory: A review of the literature' (2001) 10 Financial Markets, Institutions and Instruments 41.

Saunders, A, E Strock and N G Travlos, 'Ownership structure, deregulation and bank risk taking' (1990) 45 The Journal of Finance 643.

Stiglitz, J E, 'Principal and agent' in The New Palgrave: A Dictionary of Economics (vol 3, New Palgrave 1987).

Stout, L A, 'The mechanisms of market inefficiency' (2003) 28 Journal of Corporation Law 635.

Treasury Committee, Competition and choice in retail banking (HC 2010-11, 612-I).

Ungureanu, M C, 'Banks: Regulation and corporate governance framework' (2008) 5 Journal of Corporate Ownership and Control 449.

Walker-Arnott, 'Company law, corporate governance and the banking crisis' (2010) 7 ICR 19.

Walker, D, 'A review of corporate governance in UK banks and other financial industry entities: Final Recommendations' (2009), available at: https://www.icaew.com/en/library/subjectgateways/corporate-governance/codes-and-reports/walker-report, accessed 1 January 2014.

White, L J, 'Corporate governance and prudential regulation of banks: Is there any connection?' in J R Barth, C Lin and C Wihlborg (eds), Research Handbook on International Banking and Governance (Edward Elgar 2012). 
Williamson, O E, Markets and Hierarchies: Analysis and Antitrust Implications: A Study in the Economics of Internal Organization (Collier Macmillan 1975).

Winter, J, 'The financial crisis: Does good corporate governance matter and how to achieve it?' in E Wymeersch, K J Hopt and G Ferranini (eds), Financial Regulation and Supervision: A post-crisis analysis (OUP, 2012).

Working Group on Corporate Governance of the Basel Committee, Principles for Enhancing Corporate Governance (Nouy Daniele et al, Bank of International Settlements 2010). 